\title{
Investigation of Murine T-Cells and Cancer Cells under Thermal Stressors and 2D Slow Rotating System Effects as a Testbed for Suborbital Flights
}

Pedro J. Llanos ${ }^{1}$, Kristina Andrijauskaite ${ }^{2}$

${ }^{1}$ Applied Aviation Sciences Department, Embry-Riddle Aeronautical University, Daytona Beach, FL; ${ }^{2}$ Molecular Medicine, University of Texas Health Science Center, San Antonio, TX

Abstract

Research indicates that exposure to microgravity leads to immune system dysregulation. However, there is a lack of clear evidence on the specific reasons and precise mechanisms accounting for these immune system changes. Past studies investigating space travel-induced alterations in immunological parameters report many conflicting results, explained by the role of certain confounders, such as cosmic radiation, individual body environment, or differences in experimental design. To minimize the variability in results and to eliminate some technical challenges, we advocate conducting thorough feasibility studies prior to actual suborbital or orbital space experiments. We show how exposure to suborbital flight stressors and the use of a two-dimensional slow rotating device affect T-cells and cancer cells survivability. To enhance T-cell activation and viability, we primed them alone or in combination with IL-2 and IL-12 cytokines. Viability of T-cells was assessed before, during the experiment, and at the end of the experiment for which T-cells were counted every day for the last 4 days to allow the cells to form clear structures and do not disturb their evolution into various geometries. The slow rotating device could be considered a good system to perform T-cell activation studies and develop cell aggregates for various types of cells that react differently to thermal stressors.

Keywords

Suborbital flight $\cdot$ cell biology $\cdot$ Blue Origin $\cdot$ New Shepard $\cdot$ Sensors $\cdot$ Microgravity $\cdot$ T-cells $\cdot$ Cytokines $\cdot$ Cancer cells $•$ Cell aggregates

\section{INTRODUCTION}

There is a large body of research (Licato and Grimm, 1999; Uva et al., 2002; Gridley et al., 2009; Singh et al., 2010; Thiel et al., 2012; Hauschild et al., 2014; Martinez et al., 2015; Nickerson et al., 2016) showing that exposure to microgravity leads to suppressed immunity in both rodents and humans. The downregulation of the immune system is measured by a decreased number of T-cells, alterations in immune cell subsets, epigenetic regulation, slower proliferation rate, and other immunological parameters. Altered gravity has been shown to change gene expression in human T-cells in a time frame of $20 \mathrm{sec}$ and $5 \mathrm{~min}$ (Thiel et al., 2017) during sounding rocket and parabolic flights, and other ground-based facilities (Hauschild et al., 2015). As mentioned above, although there are many previous studies reporting microgravity-induced immune changes, there is still a lack of clear evidence on the specific reasons and precise immune mechanisms accounting for these changes. Moreover, past studies indicate microgravity-induced changes of different T-cell subsets, but they report many conflicting results (Gridley et al., 2009). In particular, variable results have been observed in lymphocyte populations (Crucian et al., 2008; Gridley et al., 2009). This suggests that T-cells might be sensitive to spaceflight conditions, pre- and post- flight procedures, and therefore such experiments require robust experimental design and pretesting. Finally, most conducted studies could not rule out the possibility that some immune changes were caused by cosmic radiation as identified in the Risk of Radiation Carcinogenesis report (NASA, 2016) or, individual body environment, and not by microgravity. Therefore, there is a great need to design robust and reproducible scientific experiments accounting for all possible confounders and test them prior to actual flights.

The majority of microgravity-based research studies are being conducted using either longer missions at ISS (International Space Station) or by employing simulated gravity technologies that we mention next. Gravitational interactions of biological systems have been investigated for decades using some of these valuable technologies, such as fast rotating clinostats, 3D clinostats, the random positioning machine (RPM), rotating wall

†Corresponding author: Pedro J. Llanos

E-mail: llanosp@erau.edu 
vessel (RWV), and high-aspect ratio vessel (HARV) devices (Kessler et al., 1998; Licato and Grimm, 1999; Paulsen et al., 2010; Mangala et al., 2011; Hauschild et al., 2016; van Loon, 2016; Manzano et al., 2018). RWV bioreactors can induce a perfusion of nutrients to the cells and waste from the cells (Klaus, 2001; Nickerson, 2016). Instead, a clinostat can be used to reproduce quiescent and unstirred fluid conditions that can be achieved in orbit. Recently, there has been a new research venue-suborbital flights platform-allowing conducting shorter missions at a lower cost and at a more frequent schedule. It is an intermediate-duration opportunity between research performed in Earth orbit and its alternatives (Moro-Aguilar, 2014). It gives scientists an opportunity to expose their biological samples to microgravity for about 3-5 min and to collect valuable scientific data that could be used to advance our knowledge on a wide range of space travel-induced side effects. Although this platform is becoming more frequently utilized; however, the information on how to prepare scientific payloads to conduct suborbital space research is still lacking.

Here, we provide findings on how performing feasibility studies lead to new insights on cells behavior and therefore influence the modifications of scientific payload design. More specifically, we exposed murine T-cells, Lewis lung carcinoma cells (LLC), breast cancer cells MCF7, and colon cancer cells HCT116 to thermal and vibration conditions, similar to those experienced during the suborbital flight. Although vibration testing is encouraged by the flight provider, it was not mandatory for our experiment, yet our team conducted some vibration tests as explained in the section Methods. Thus, we preconditioned T-cells with commonly used interleukins, IL-2 and IL-12, to investigate their potential in enhancing cells survivability. These two cytokines are not only known to play a key role in T-cell activation and proliferation, but they are also used in immunotherapy regimes against cancer (Wang et al., 2017; Choudhry et al., 2018). In fact, it has been suggested that the loss of microgravity-induced T-cell activation might be due to the inhibition of early IL-2 receptor expression (Cogoli, 1997; Martinez et al., 2015), which was also the basis for the STS-107 flight. The role of IL-12 in microgravity is less investigated compared to IL-2 (Bakos et al., 2002; Li et al., 2013). However, given its positive impact on T-cell activation, survival, and function (Rubinstein et al., 2015), more research is needed to explore its potential role in helping T-cells to restore microgravity-induced immunity downregulation.

Given conflicting results derived from previous studies and assuming that cells might be sensitive to numerous external factors, we sought to determine if exposure of T-cells and cancer cells to physiological stressors will affect their survival and whether this type of cells could be used for suborbital flight missions without compromising their viability. Although the actual suborbital flight lasts for about
15 min, preparation for cancer cells and especially T-cells for a flight is a long process. Isolated splenocytes need to first be activated ( $48 \mathrm{~h}$ ), so that they could mature into activated T cells. Often suborbital flights are delayed and therefore it is hard to estimate on what day of postactivation these cells will be flown. Therefore, we suggest exposing cells to a slow rotating system for a longer period than the actual suborbital flight to assess the feasibility of these cells to survive and be suitable for suborbital space flights. Our results indicate that different cells behave differently when exposed to suborbital spaceflight stressors. Thus, our findings demonstrate that the addition of IL-2 and IL-12 to T-cell cultures provides a simple way to improve the survivability of cells.

\section{MATERIALS AND METHODS}

\section{Splenocyte Isolation}

After sacrifice, C57BL/6 (B6) mice spleens were aseptically removed and placed in Roswell Park Memorial Institute (RPMI) 1640 medium. Spleens were smashed through sterile nylon mesh followed by red blood cell ammonium-chloridepotassium (ACK) lysing buffer. Then cells were re-suspended in RPMI 1640 supplemented with I-glutamine $(2 \mathrm{mM})$, penicillin $(100 \mathrm{U} / \mathrm{mL})$, streptomycin $(0.1 \mathrm{mg} / \mathrm{mL}), 2-M E\left(5 \times 10^{-5} \mathrm{M}\right)$, and heat-inactivated fetal bovine serum (FBS) $(10 \%)$. Given many T-cells needed, several spleens were pooled together to set up T-cell cultures, unless stated otherwise, such as in Figure 3.

\section{T-Cell Activation}

Isolated splenocytes were placed in either T25 flasks at $3 \times 10^{6}$ cells $/ \mathrm{mL}$ concentration or in 24-well plates at $1 \times 10^{6}$ cells $/ \mathrm{mL}$ concentration and activated with anti-CD3 $\mathrm{mAb}$ (145-2C11 clone, plate-bound, $1 \mathrm{mg} / \mathrm{mL}$ ) and anti-CD28 mAb (37.51 clone, soluble, $2 \mathrm{mg} / \mathrm{mL}$ ) in RPMl 1640 medium for $48 \mathrm{~h}$ with and without IL-2 $(200 \mathrm{ng} / \mathrm{mL})$. We adjusted T-cell concentrations in T25 flasks and 24-well plates based on the different surface area and volume. Thus, our past experiments suggest that these different concentrations used for different containers lead to the best activation results. Cells were then transferred in an incubator and observed on a daily basis to assess their growth. After $48 \mathrm{~h}$, cells were washed, counted, and cultured with or without additional cytokines including human (h) IL-2 (200 ng/mL) and mouse (m) IL-12 (10 ng/mL) for different time points.

\section{Cancer Cells}

All cancer cell lines were obtained from American Type Culture Collection (ATCC). Lewis lung carcinoma (LLC) lung cancer cells were cultured in modified Dulbecco's modification of 
Eagle medium (DMEM) supplemented with 10\% FBS. Human breast cancer cells MCF7 and human colon cancer cells HCT116 were cultured in Eagle's minimum essential medium and McCoy's 5A medium, respectively, both supplemented with $10 \%$ FBS.

\section{Thermal, Vibration, and Centrifugation Procedures}

After activation, T-cells and cancer cells were centrifuged for $5 \mathrm{~min}$ at $8.35 \mathrm{~g}$ (since they were centrifuged at $300 \mathrm{rpm}$ at a radial distance of $8.3 \mathrm{~cm}$ ). The reason we exposed cells this long is because the suborbital flight is expected to have several segments between $1 g$ and $3 g$ during ascent for about $2.5 \mathrm{~min}$, between $1 \mathrm{~g}$ and $5 g$ during descent for nearly $1.5 \mathrm{~min}$, and some instances with accelerations between $2 \mathrm{~g}$ and $3 g$ during parachute recovery for almost $30 \mathrm{sec}$, total time of about $5 \mathrm{~min}$. Then they were either placed in 2, 5, or $15 \mathrm{~mL}$ tubes with and without cytokines and maintained in water baths at the following temperatures: $37^{\circ} \mathrm{C}, 30^{\circ} \mathrm{C}, 34^{\circ} \mathrm{C}$, and $40^{\circ} \mathrm{C}$ for various time points. Cells were also exposed to other thermal baths at $10^{\circ} \mathrm{C}$ and $20^{\circ} \mathrm{C}$ to account for extreme temperature variations during launch conditions as we will refer to later.

T-cells and both breast and colon cancer cells were exposed to different levels of vibrations $(20,30,40,60$, and $125 \mathrm{~Hz}$ ) for 1 minute in all three axes using the Troemner talboys advanced digital 1000MP microplate shaker. The tubes were held and taped onto the flat surface of the shaker. Sensors placed in the Blue Origin's Crew Capsule (Blue Origin, 2016, 2018) have measured a vibration environment of $80 \mathrm{~Hz}$ in the plane parallel to the floor of the payload locker that housed our experiment, and larger vibrations above $80 \mathrm{~Hz}$ were observed in the direction of motion of the rocket.

\section{D Slow Rotating System}

After T-cell activation, $48 \mathrm{~h}$, cells were transferred into either $15 \mathrm{~mL}$ conical tubes, $5 \mathrm{~mL}$ or $2 \mathrm{~mL}$ Eppendorf tubes, supplemented with or without additional cytokines and placed in a slow rotation system for 116-140 h continuously. After rotation, cells were photographed and counted.

The tubes were placed at a radial distance, $R$, of $8.35 \mathrm{~cm}$ and 80 degrees angle. The slow rotation system completes one revolution every $20 \mathrm{~min}$, so the angular velocity, $\omega$, is $0.05 \mathrm{revs} / \mathrm{min}$. With these two values, we can compute the relative centrifugal force (RCF) using the equation (Eppendorf Handling Solutions, 2018) below:

$$
R C F=11.18 * R *\left(\frac{\omega}{1000}\right)^{2}=2.33 * 10^{-7} ; R(\mathrm{~cm}) ; \omega(\mathrm{rev} / \mathrm{min})
$$

The centrifugal force calculation can be checked with another equation (United Nations, 2013):
$R C F=1.12 * 10^{-3} * R * \omega^{2}=2.33 * 10^{-7} ; R(\mathrm{~m}) ; \omega(\mathrm{rev} / \mathrm{min})$

Therefore, the acceleration felt by the cells inside the tube was $2.29 * 10^{-6} \mathrm{~m} / \mathrm{s}^{2}$ or $2.33 * 10^{-7} \mathrm{~g}$.

\section{Cell Counting}

Cells were counted using hemocytometer and Trypan Blue $(0.4 \%)$ solution. Only viable cells were included into final cell number counts.

\section{Phase Contrast Microscopy}

The MOTIC Inverted Microscope (AE21) was used for visual observation of the morphology of the cells using the following objective lenses: CCIS E Plan Achromat 4X/0.10, W.D. 14.2 FOV 20, CCIS E Plan Achromat 10X/0.25, W.D. 6.3 FOV 20, and CCIS E Plan Achromat LWD 20X/0.40, W.D. 5.5 FOV 20.

\section{RESULTS}

\section{Cell Activation and Preparation for Experimental Procedures}

To test the feasibility of generating and recovering viable cells after the launch is the key objective of our prospective scientific experiment, as the failure to retrieve viable cells will lead to the failure of the whole mission. In our prospective flights, we plan on using both T-cells and cancer cells, therefore we assessed both of them in this feasibility study. Also, given that other researchers reported conflicting data from microgravity-based experiments, we believe that some conflicting findings may have been caused by the lack of proper controls and experimental procedures conducted prior to actual flights, such as insufficient information on how long cells could survive after being removed from the incubator, what temperatures they are most sensitive to, what is the best method to activate cells, etc. Therefore, it is necessary to document all procedures for reproducibility and research integrity purposes. Figure 1 depicts cells before T-cell activation and preparation for thermal and centrifugation testing. T-cell activation is an essential component of the adaptive immune response, mediating many responses including cytokine and antibody production, killing of infected or transformed cells, and tolerance to self-antigens. Therefore, it is critical to have appropriately activated cells. Some indicators of proper T-cell activation include the change of color and the formation of T-cell clusters. The visually observed more yellowish color indicates the change in $\mathrm{pH}$ as a result of the faster metabolism of cells. In addition, well-activated T-cells are known to form microclusters or aggregates of cells, caused by molecules recruited to activated T-cell receptor sites (Sherman et al., 2013). T-cells that were not activated, as in Figure 1A, 1B 
A

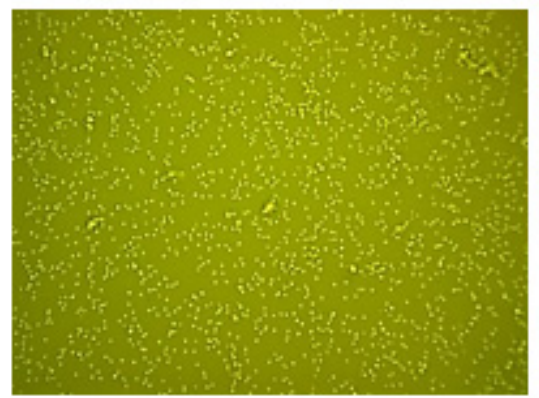

E

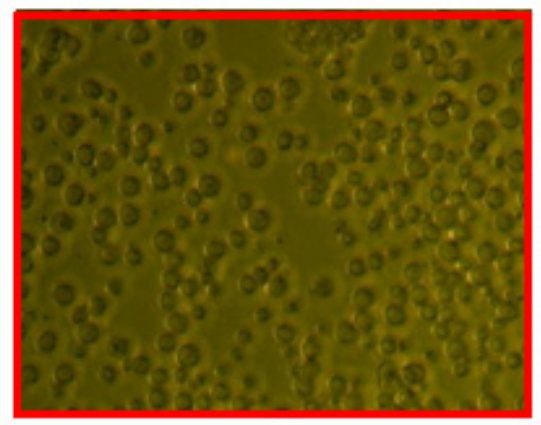

H

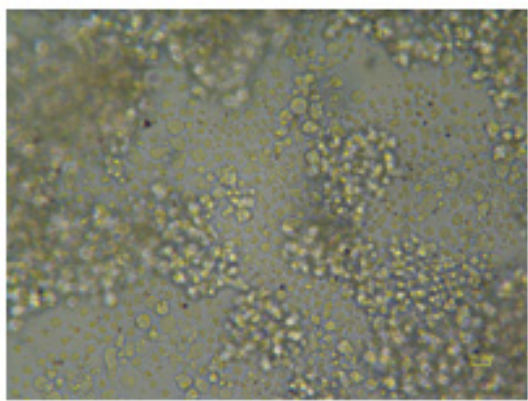

B

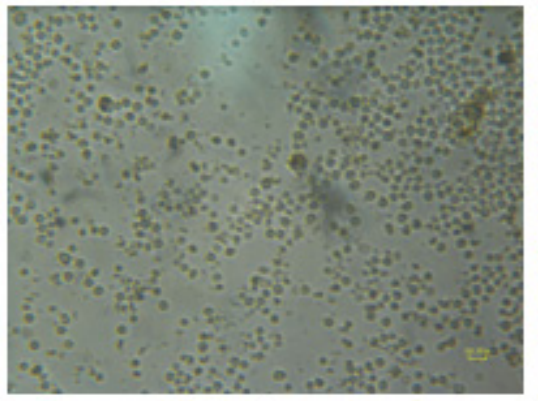

$\mathbf{F}$

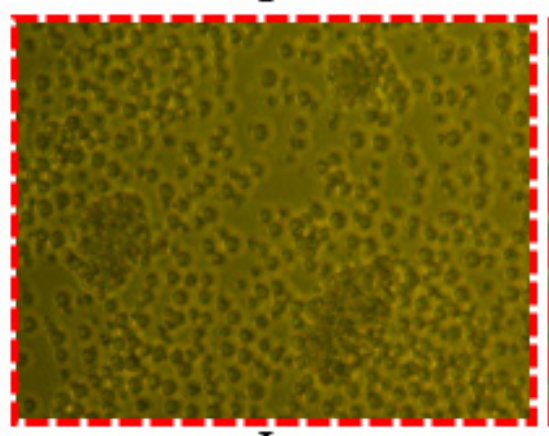

I

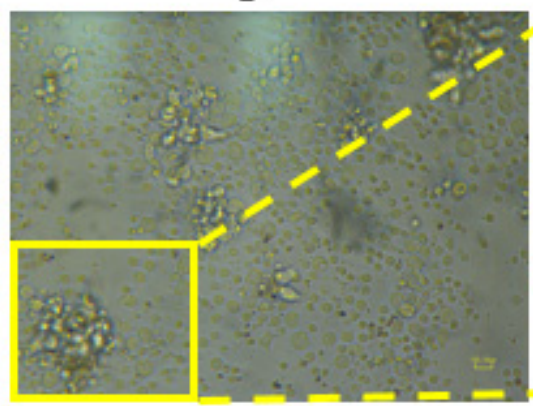

C

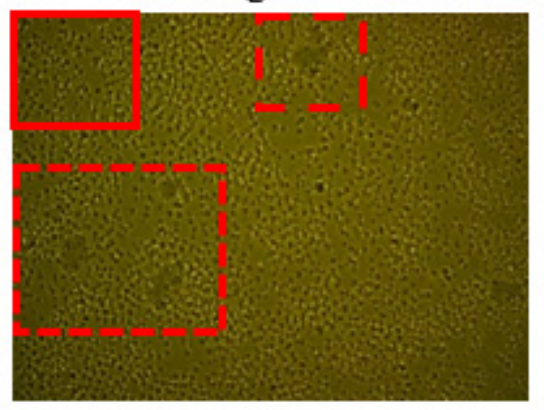

G

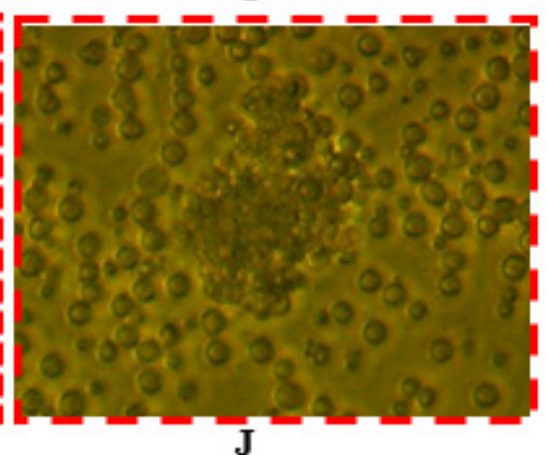

$\mathbf{J}$

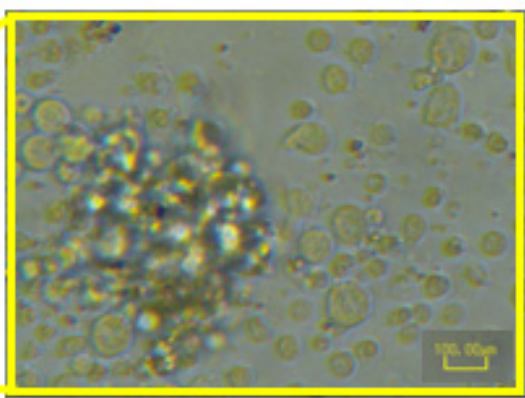

Figure 1. Phase contrast microscopy. Evolution of T-cells after activation. Representative pictures of microscopic fields of each condition from two independent experiments. (A) and (B) Not activated cells (unstimulated). (C) Stimulated T-cells (primed with cytokine IL-2) after 2 days of activation. $(E),(F)$, and $(G)$ Zoomed sections of $(C)$ as indicated by the solid, dotted, and dashed lines enclosing each boxed section. (H) Stimulated T-cells (not primed with cytokine). (I) Stimulated T-cells with IL-2. (J) Zoomed sections of (I) after 2 days of activation. A, B, C: 4× magnification, E, F, H, I: 10× magnification, J: 40× magnification; bar $100 \mathrm{~mm}$.

showed less dense regions. Since these were not activated, T-cells remained localized while waiting to be activated by a specific T-cell receptor. Figure $1 \mathrm{C}$ depicts stimulated T-cells primed with IL-2, which seemed to have been enhanced more since they are showing about half a dozen visible aggregates. Figure $1 \mathrm{E}, 1 \mathrm{~F}$, and $1 \mathrm{G}$ are zoomed sections of Figure 1C, showing large aggregates between 200 and 400 $\mathrm{mm}$ after 2 days of activation. Figure $1 \mathrm{H}$ shows a snapshot of the T-cells, which were stimulated (but not primed with IL-2) showing T-cells starting to form aggregates, and Figure $1 \mathrm{I}$ is another snapshot of the T-cells, which were stimulated and also primed with IL-2 cytokine, these show more well defined clear formation of T-cell aggregates of different sizes between
200 and $500 \mathrm{~mm}$. Figure $1 \mathrm{~J}$ is a zoom of Figure $1 \mathrm{l}$ illustrating a large aggregate of $500 \mathrm{~mm}$ after 2 days of activation.

One of the most common ways to activate T-cells is using separately or together anti-CD3/CD28 antibodies that provide a costimulatory signal through the T-cell receptor (TCR). Naive cells not stimulated with these antibodies do not mature into activated T-cells. As shown in Figure 1A, 1B, not activated cells remain small size (50 to about $100 \mathrm{~mm}$ ) and do not form large clusters. Activated cells on another hand (Figure 1C, $1 \mathrm{H}$ ) usually start forming larger size clusters (50 to about $150 \mathrm{~mm}$ ), which were visualized using a higher magnification microscope. The solid red box, dashed box, and dotted box correspond to three different zoom sections depicted in Figure 
1C. The solid box illustrates the top left corner of Figure 1C, which shows higher motility than when T-cells are not activated (Figure 1A). These T-cells are slowing conglomerating to form aggregates. Figure $1 \mathrm{~F}$ shows three aggregates forming within the dotted box and Figure 1G depicts one of the largest aggregates of near $500 \mathrm{~mm}$.

After activation, cells were transferred into $15 \mathrm{~mL}$ conical tubes to undergo centrifugation for $5 \mathrm{~min}$. The next step was to place the cells in various $2 \mathrm{~mL}$ Eppendorf tubes and put them in a thermal bath at various temperatures. Cells were extracted from each of the thermal baths to assess the survivability.

\section{Thermal and Centrifugation Study Using Murine T-cells and Lung Cancer Cells}

Our results show (Figure 2) the survival rate of murine T-cells under different thermal stressors: at $37^{\circ} \mathrm{C}$ (reference temperature), $30^{\circ} \mathrm{C}, 34^{\circ} \mathrm{C}$, and $40^{\circ} \mathrm{C}$ for the first batch of cells (with no cytokines) during the first feasibility study. Although we knew the temperature of the capsule could be as low as $20^{\circ} \mathrm{C}$, we chose these upper range temperatures because this would be the range of temperatures more suitable for cell growth, since these temperatures would be encountered during launch in the summer at the time we were told the flight was going to occur, and our team performed our first feasibility study. However, given the flight was postponed several times, our team decided to conduct a second feasibility study (explained later) in which lower temperatures were considered to accommodate the environmental conditions inside the New Shepard's Crew Capsule (CC), which were going to be as low as $20^{\circ} \mathrm{C}$ and as high as $32.2^{\circ} \mathrm{C}$ (Blue Origin, 2016). Note that these conditions have been modified as per November 2018, now between $\sim 10^{\circ} \mathrm{C}$ and $32.2^{\circ} \mathrm{C}$. (Blue Origin, 2018). In our previous flight, the temperature measured inside the NanoLab $(10 \mathrm{~cm} \times 10 \mathrm{~cm} \times 20 \mathrm{~cm})$ in the $\mathrm{CC}$ reached temperatures as low as $13^{\circ} \mathrm{C}$. This was addressed to the Blue Origin and the NanoRacks teams at the payload processing facility (PPF) after analyzing the data about the scrubbed launch on December 11th 2017. After having exposed cells to a thermal bath at these temperatures, and quantified the cells, we noted that cells at $37^{\circ} \mathrm{C}$ showed the highest number of cells after one day. The next two days, the cells exposed at $34^{\circ} \mathrm{C}$ and $37^{\circ} \mathrm{C}$ were counted yielding $0.5 \mathrm{M}$. Cells exposed to $40^{\circ} \mathrm{C}$ yielded the lowest number of cells with about $0.3 \mathrm{M}$, while the cells exposed to $30^{\circ} \mathrm{C}$ yielded the largest number of cells, about 0.7 $\mathrm{M}$. This indicates that cells preferential temperature is $30^{\circ} \mathrm{C}-$ $37^{\circ} \mathrm{C}$ (Figure $2 \mathrm{~A}$ ).

In the second feasibility study (Figure 2B), we exposed LLC to similar thermal stressors: at $37^{\circ} \mathrm{C}$ (reference temperature), $10^{\circ} \mathrm{C}, 20^{\circ} \mathrm{C}$, and $30^{\circ} \mathrm{C}$ but lower thermal temperature than the reference temperature. The reason for these temperatures is that the Payload Users Guide (Blue Origin, 2017) indicated that the temperature inside the New Shepard Crew Capsule was between $20^{\circ} \mathrm{C}$ and $32.2^{\circ} \mathrm{C}$. Yet, we decided to conduct a thermal study at $10^{\circ} \mathrm{C}$ because of the possibility for the flight to be delayed. It is important to account for the unexpected as it may result in the loss of the science payload (there was no active thermal system in the capsule on December 2017). After 6 days, the viability of the cells at $10^{\circ} \mathrm{C}$ showed the lowest yield of cells to almost none, whereas cells exposed to $30^{\circ} \mathrm{C}$ and $20^{\circ} \mathrm{C}$ yielded the largest number cells with about $2 \mathrm{M}$ and $1.1 \mathrm{M}$, respectively. Finally, cells exposed at the reference temperature yielded near $1 \mathrm{M}$. These findings suggest that if cells are exposed to really low temperatures, such as $10^{\circ} \mathrm{C}$, they will not be able to survive. Therefore, observing cells behavior kept at different temperatures, urged the team to make certain modifications, such as installation of a second thermal layer in the NanoLab.

The third feasibility study (Figure $2 \mathrm{C}$ and $2 \mathrm{D}$ ) included T-cells primed with IL-2 cytokine (Figure $2 \mathrm{C}$ ) and with IL-12 cytokine (Figure 2D), which were exposed to $10^{\circ} \mathrm{C}, 21^{\circ} \mathrm{C}$, $30^{\circ} \mathrm{C}$, and $37^{\circ} \mathrm{C}$ for about 5 days. These three studies were conducted at the Medical University of South Carolina (MUSC). Our third study also indicated that cells would die faster when exposed to $10^{\circ} \mathrm{C}$, after $24 \mathrm{~h}$ the number of cells decreased by $75 \%$ for its initial harvest. Importantly, our data show that cells primed with IL-2 or IL-12 had a slight longer survival rates with larger yields. Control cells and IL12 primed cells (Figure $2 \mathrm{C}$ ) showed yields with about $0.7 \mathrm{M}$ cells at the end of the 5 days, compared to $1 \mathrm{M}$ cells for the IL-2 primed cells. At $37^{\circ} \mathrm{C}$, the cells with IL-2 had the largest yield for this temperature condition with about $1.5 \mathrm{M}$, the other two conditions (control and IL-12, Figure 2D) had about 0.5 $0.6 \mathrm{M}$. Cells (with IL-2) exposed to $30^{\circ} \mathrm{C}$ yielded the largest number of cells with about $2.7 \mathrm{M}$. Finally, Figure 2E indicates the color change across different conditions. As mentioned before, the preferential temperature of T-cells is $30^{\circ} \mathrm{C}-37^{\circ} \mathrm{C}$, which is reflected by our cell counts and the color change.

\section{Simulated Gravity Study Using 2D Slow Rotation System for $116 \mathrm{~h}$}

An additional feasibility study was conducted at the University of Texas Health Science Center in San Antonio (UTHSCSA) (Figures 3 and 4 ) in which we tested T-cell survivability after $116 \mathrm{~h}$ continuously exposure to $2 \mathrm{D}$ slow rotation system rotation. We used splenocytes for activation derived from multiple mice belonging to the same strain. We sought to determine whether there was a difference in T-cell activation rates among different spleens (Figure 3 ).

After three days in the slow rotation system, cells were observed under the microscope. As seen in Figure 3B, cells with IL-2 showed four of the largest cell aggregates for spleen 1 and 4 smaller aggregates for spleen 2. Cells with no IL-2 showed lower growth than for the other two spleens (center Figure 3B). Cells obtained from the third spleen, which also 
A

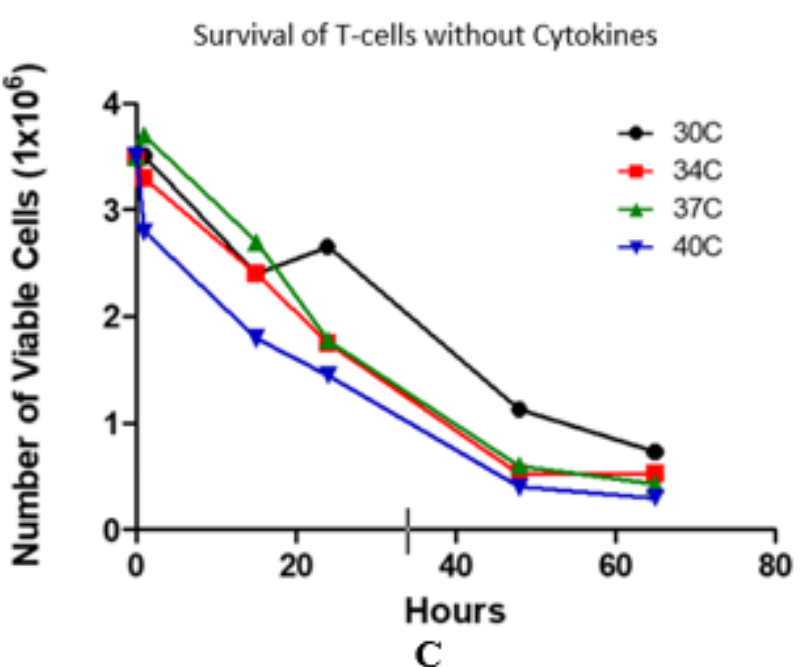

C

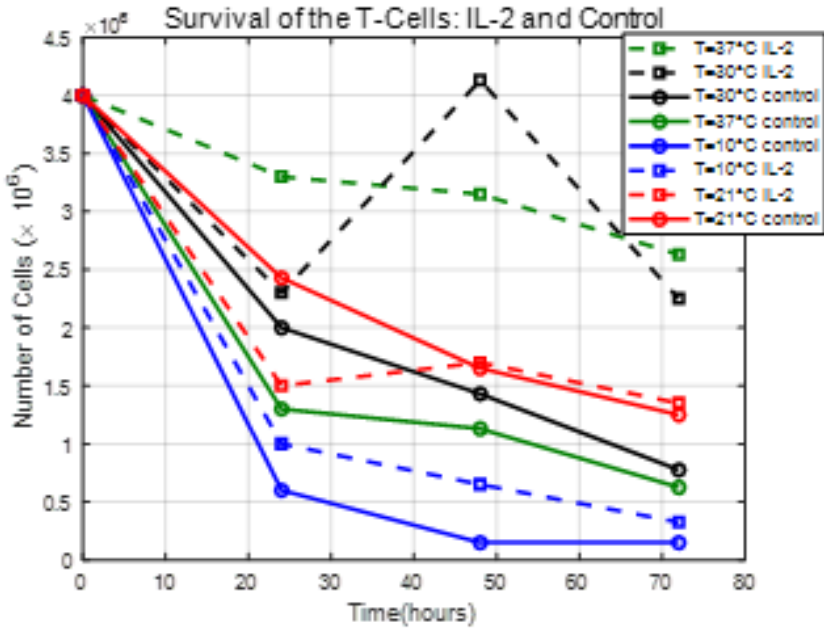

B

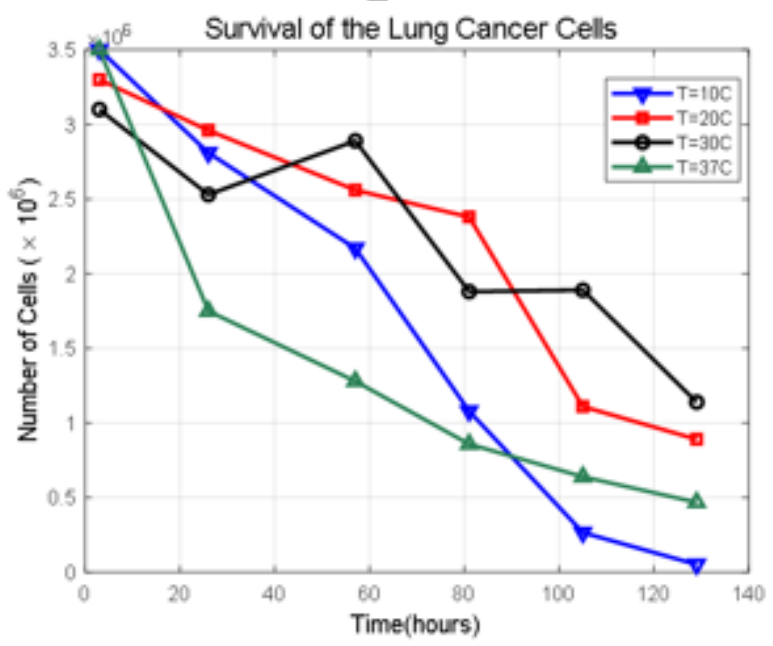

D

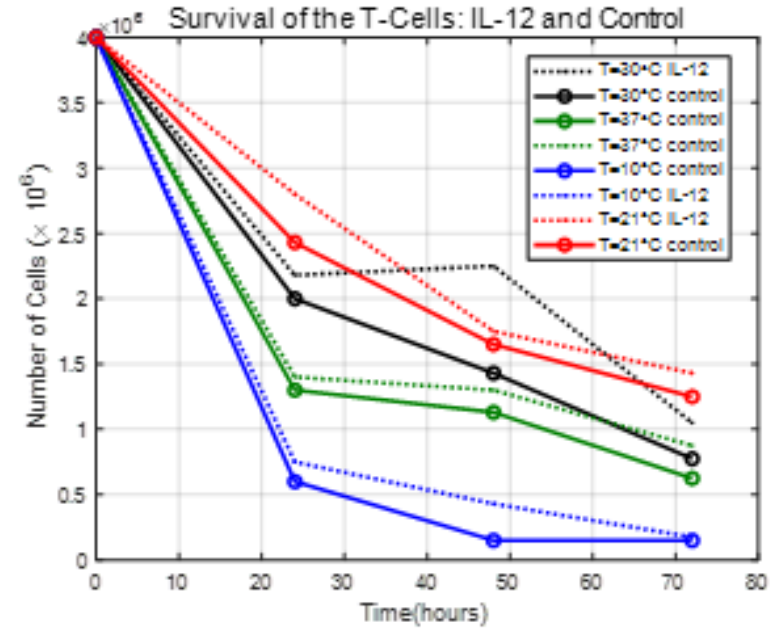

$\mathbf{E}$

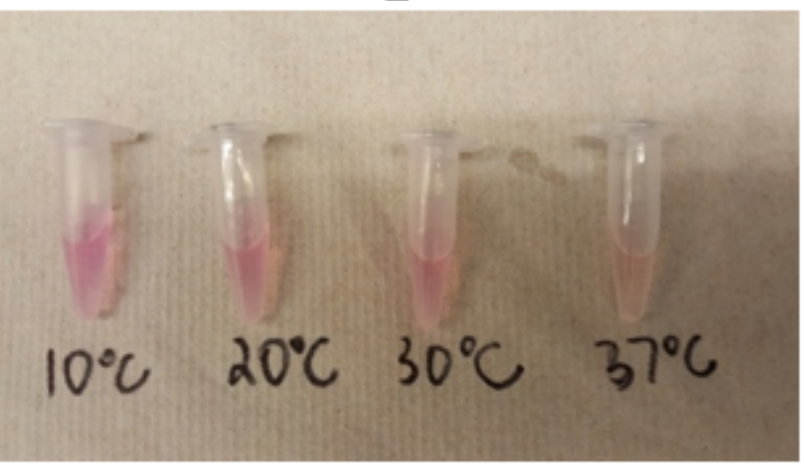

Figure 2. Survival rate of T-cells exposed to various temperatures for the indicated time (in hours). (A) T-cells with no cytokines (single experiment). (B) Lung cancer cells (LLC) (single experiment). (C) T-cells primed with IL-2 cytokine and compared with control (single experiment). (D) T-cells primed with IL-12 cytokines and compared with control (single experiment). (E) Color differentiation of lung cancer cells. 

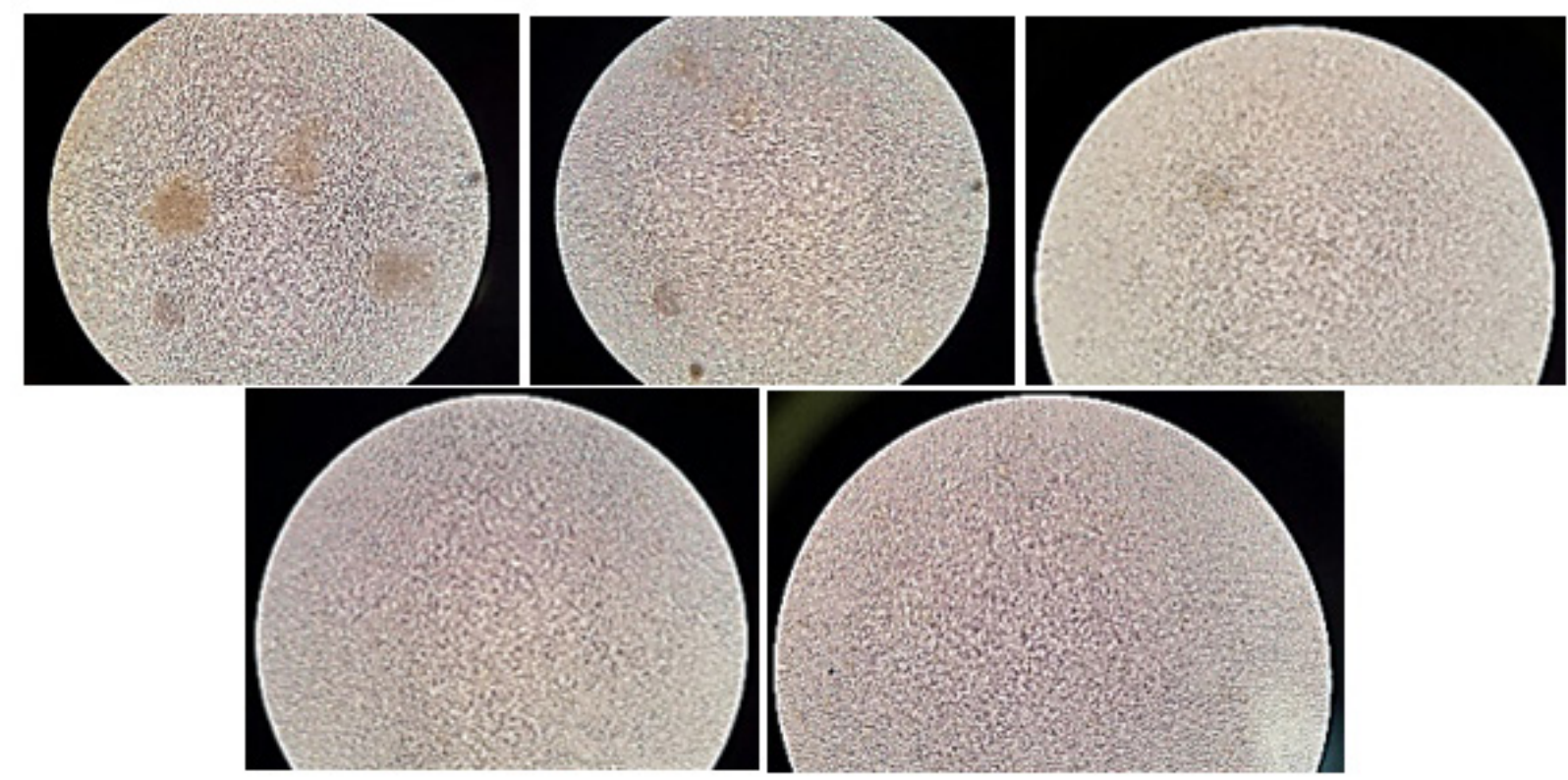

B
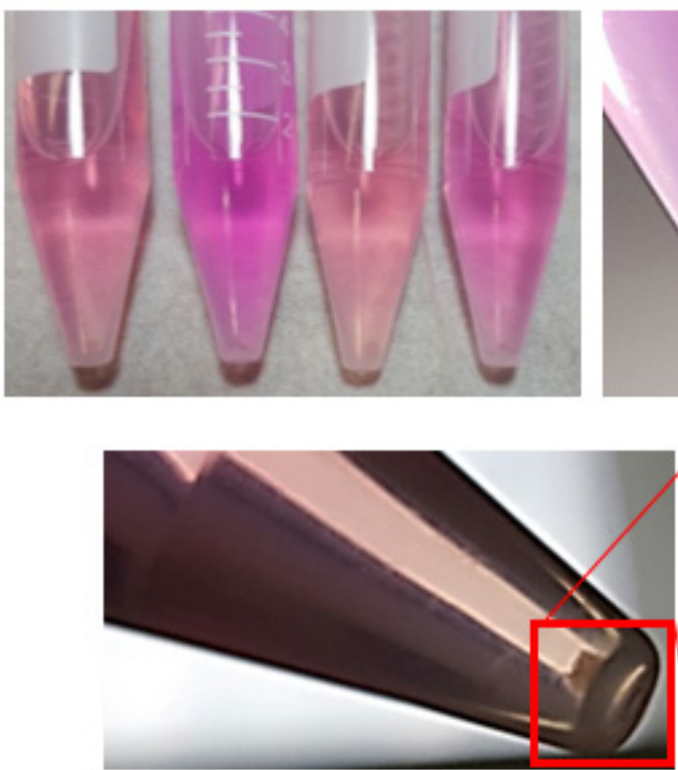

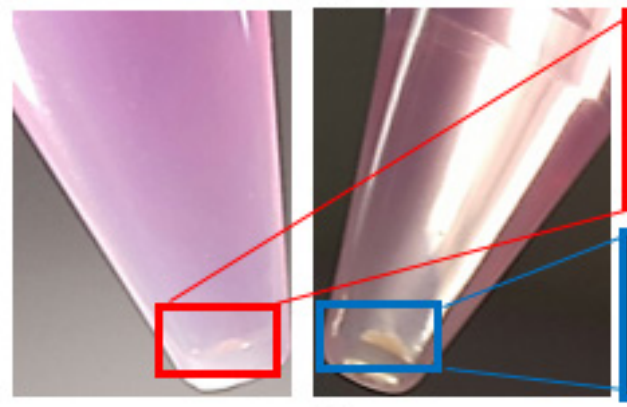

C

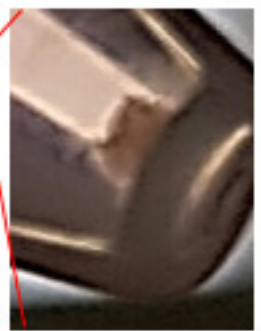

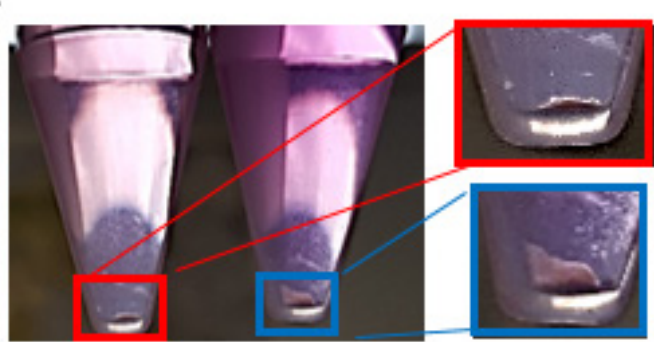

Figure 3. T-cells aggregates formation after being exposed to a slow rotation system for 3 days. (A) Cell structures from L to R: spleen 1 with IL-2 activation, spleen 2 with IL-2 activation, spleen 2 with no IL-2 activation, spleen 3 with IL-2 activation, spleen 3 with no activation, $4 \times$ magnification. (B) four tubes (control, IL-2, IL-12, IL-2/IL-12); Control (center); IL-2 (right). Zoomed sections of control and IL-2 are five times larger as shown in the far right. (C) IL-12. Zoomed section is twice larger; comparison of IL-2 and IL-12. Zoomed sections are four times larger. Microscopy images represent two independent experiments. 
A

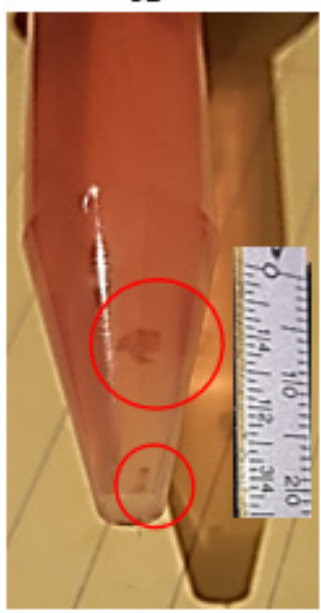

B

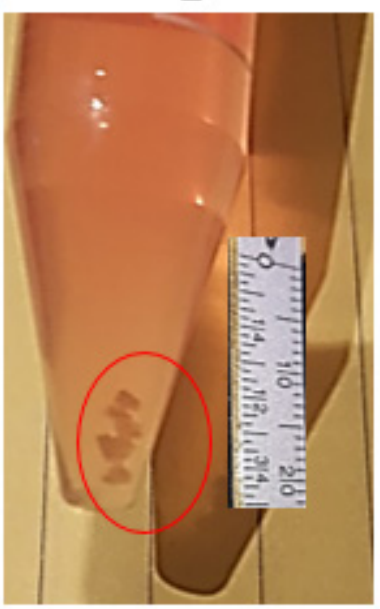

E
C

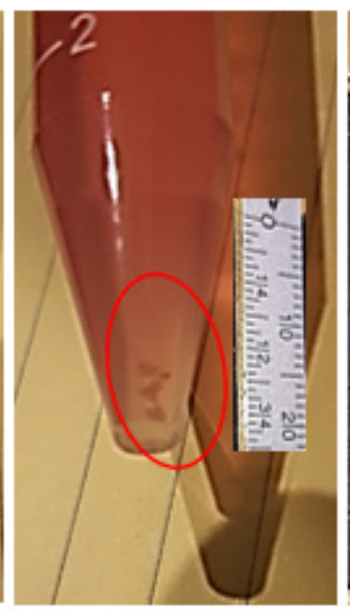

G

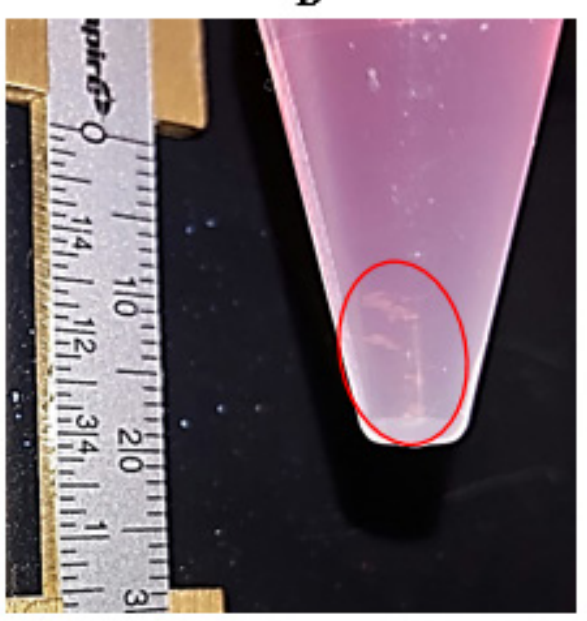

H
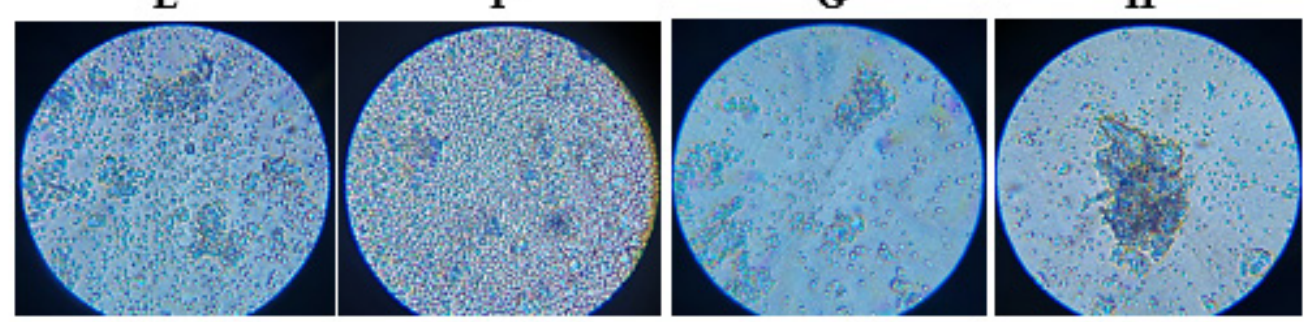

Figure 4. Formation of T-cell aggregates in a slow rotation system after 3 days. (A). Aggregates of cells in IL-2. (B) Cells in IL-12. (C) Cells in IL-2/IL-12. (D) Early stages (+1 days) of cells in IL-12 forming swirling-like aggregates or frond-like structures $\sim 3 \mathrm{~mm}$ long. (E), (F), and $(\mathrm{G})-(\mathrm{H})$ are pictures of T-cells clusters for IL-2, IL-12, and IL-2/IL-12, respectively at $4 \times$ magnification. Microscopy images represent one independent experiment.

had IL-2, did not show signs of cell growth or at least in comparison with the cells from spleen 1 and 2. Lastly, cells with no IL-2 activation from the third spleen did not show much growth either. It was important to not combine splenocytes derived from different spleens during the activation process, as we learned that even using the same strain of mice could lead to different outcomes of T-cell activation and stimulation.

As for cells with IL-12, it was observed (Figure 4) swirlinglike aggregates with larger geometries and with frond-like structures of about 3-4 mm in length after 3 days in the slow rotation system. We observed that aggregates become denser the more time they are exposed in the slow rotation system. After 5 days in the slow rotation system, aggregates were dense enough to form a sheet of cells similar to a 3D tissue aggregate (Figure $5 \mathrm{~A}$ ) that is not breakable when exposed to vibrations for a few seconds. Cells come in contact, which allows junctions between cells to form under low-fluid shear conditions, which sets the ideal conditions to form more stable and larger 3D aggregates. Although our study was not intended to quantify the fluid shear stress on the cells, previous investigations (Grimm et al., 2014; Mehri et al., 2018) on blood cells attribute the formation of aggregates under very low shear stress. Values of these shear stresses can be as small as $6 \mathrm{mPa}\left(0.06 \mathrm{dyne} / \mathrm{cm}^{2}\right)$ to about $50 \mathrm{mPa}(0.5$ dynes $/ \mathrm{cm}^{2}$;Grimm et al., 2014). Low-fluid shear environments are thought to be the main beneficial factors to generate functional tissues (Nickerson et al., 2016) while high-fluid shear environments can be deleterious to the configuration of tissues or constructs. These constructs could be considered clinically relevant to further study the effects of spaceflight on human tissue and advance our understanding of mechanisms that may affect tissue loss or deconditioning during extended periods in space. And although platforms such as the RWV can produce a low-shear environment, sometimes referred to as low-shear modeled microgravity (LSMMG), our low rotation device has been proved to generate aggregates too. Fluid shear LSMMG environment (Nickerson et al., 2016) can fluctuate in fluid shear levels ranging from $0.4 \mathrm{~Pa}$ (4 dynes/ $\mathrm{cm}^{2}$ ) to $5 \mathrm{~Pa}\left(50\right.$ dynes $\left./ \mathrm{cm}^{2}\right)$ along the blood vessel walls, $<0.1 \mathrm{~Pa}\left(1 \mathrm{dyne} / \mathrm{cm}^{2}\right)$ in the utero, and $<1 \mathrm{mPa}$ (0.01 dynes/ $\left.\mathrm{cm}^{2}\right)$ in cells. 


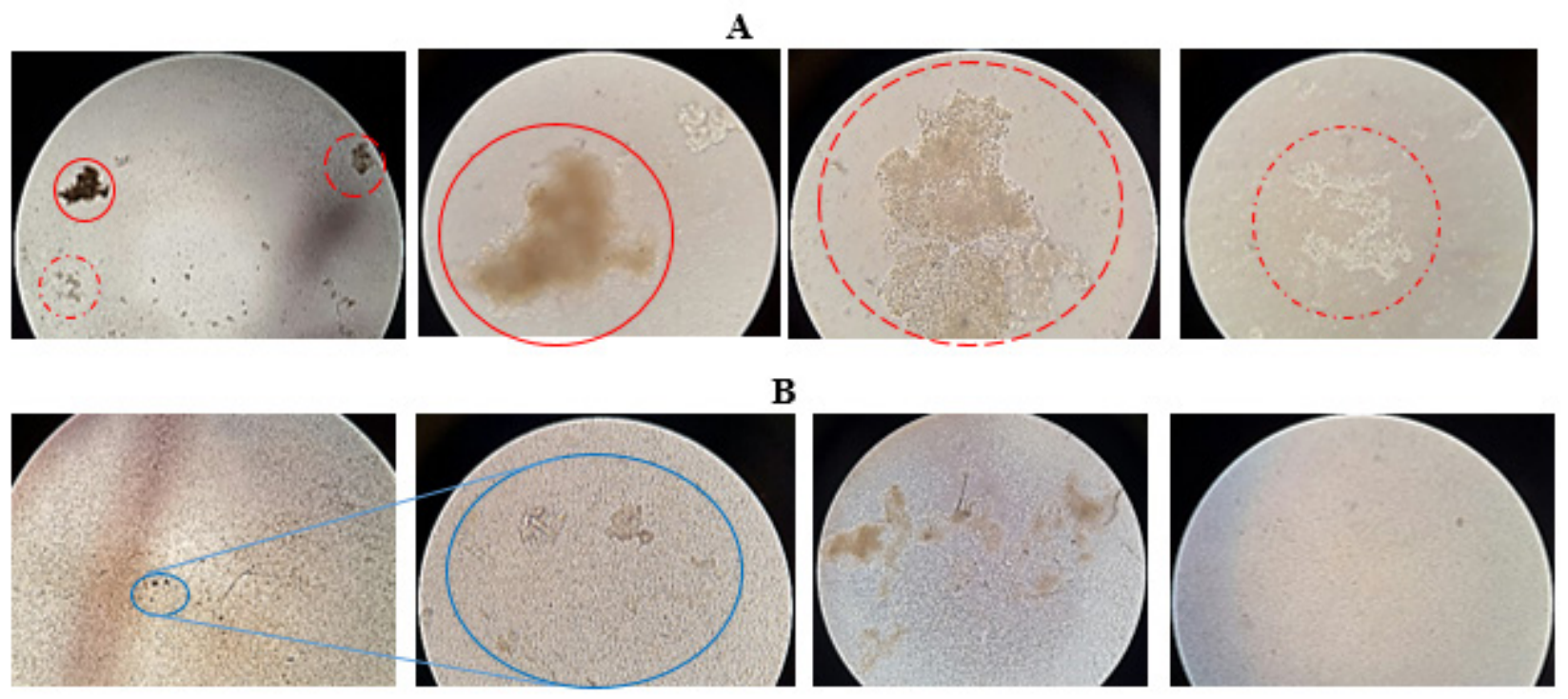

Figure 5. Formation of aggregates after $116 \mathrm{~h}$ of slow rotation system operation at $4 \times$ magnification. (A) Three large cell structures with IL-2; zoom of each of the three large structures shown in first left picture of A. (B) Cell structures in control (first two pictures); cell structures in IL-12 (third picture); cell structures in IL-2/IL-12 (last picture). Microscopy images represent one independent experiment.

Figure 4 shows some detailed aspects of these cell structures after spending 3 days in the slow rotation system. Note that these frond-like structures were formed when the cell culture was exposed to a slow rotation in the lab. In Figure 5, we retrieved the cells from the clinostat after $116 \mathrm{~h}$ in operation, placed the cells in different plates, and took several snapshots for each condition. Given our objective was to investigate the effect of different cytokines across various slow rotating system conditions and not to compare this effect to the $1 \mathrm{~g}$, we did not set up a normal gravity control that would have been beyond the scope of this particular study.

The first picture (top left) in Figure 5A illustrates several aggregate formations, which are then zoomed in individually (solid circle, dashed circle, and dotted-dashed circle) and depicted in the other three pictures of Figure 5A. Once again, these aggregate structures were in a medium with IL-2 highlighting a strong formation of aggregates in the presence of this cytokine. The third picture in Figure 5B depicts other formation of aggregates in the presence of IL-12, perhaps more scattered than and not as defined as the ones as the aggregates with IL-2. The last picture in Figure 5 shows very tiny aggregates in the presence of both IL-2 and IL-12. Finally, the first picture in Figure 5B shows lots of cells and although they seem to come closer they do not consolidate in the aggregate formation and the minimum handshake performed dilutes this formation away. However, similar shakes of aggregates in the presence of IL-2 or even IL-12 do not alter the geometry of such structures. At the end of our experiment, we did hand-shake these aggregates and were unable to break the structures of the main aggregates.

\section{Simulated Gravity Study Using 2D Slow Rotation System for $140 \mathrm{~h}$}

Building upon our previous feasibility study for $116 \mathrm{~h}$, we carried out another experiment for an extended time of T-cells to slow rotation to about $140 \mathrm{~h}$ (near 6 days) to assess the viability of the cells. Our goal was to duplicate sets of experiments and assess any differences in the viability of the cells. T-cells in Figure 9 (3-5 days in slow rotation) and Figure 8 (6 days in slow rotation) also revealed similar frond-like structures (up to $1 \mathrm{~cm}-1.5 \mathrm{~cm}$ in length) similar to the ones formed in Figure 4 (3 days in slow rotation). These structures seemed more stable and showed larger 3D tissue aggregates than the ones reflected in Figure 7, perhaps because the cells were exposed to the slow rotation for a longer time. This suggests that longer exposure to slow rotation yields larger and longer 3D aggregates or frond-like structures. Small bubbles appeared occasionally and for a short amount of time (order of minutes) when we opened the tubes to count cells.

We had T-cell conditions in duplicate, as one set was devoted to imaging, while another set was set up for counting purposes. Figure 6 indicates the T-cell numbers derived from two independent experiments. The first experiment (solid bars) resulted in the following counts: 3.33 million T-cells for control, 3 million T-cells for IL-2, 1 million T-cells for IL-12, and 3.2 million T-cells for IL-2/12. T-cells formed large pellets that were visualized in the microscope. T-cells from the second 


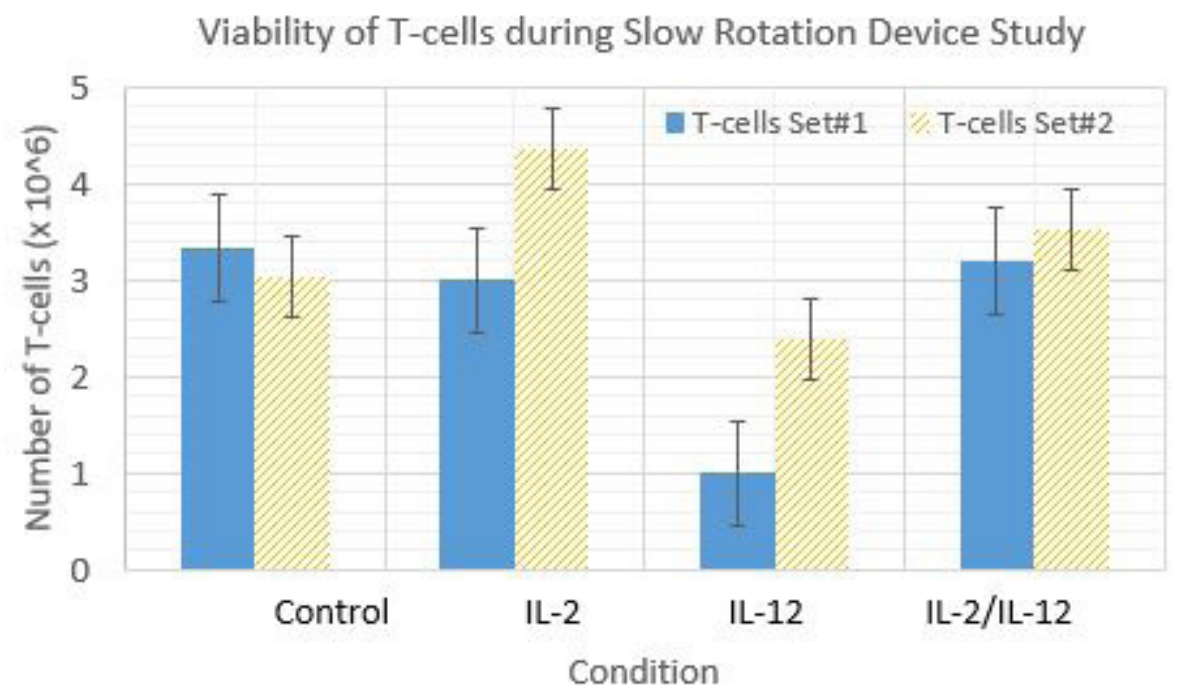

Figure 6. T-cells counts (with standard errors) during slow rotation system study after $140 \mathrm{~h}$ obtained from two separate sets of cells from two independent experiments.

experiment (pattern fill) yielded the following numbers: 3.04 million cells for control, 4.37 million cells for IL-2, 2.38 million cells for IL-12, and 3.52 million cells for IL-2/IL-12 (Figure $6)$. The mean $\pm S D$ for each set of cells were $2.63 \pm 0.95$ and $3.33 \pm 0.73$, respectively. The difference between each condition for these two sets were 0.29 million cells for control and 0.32 million cells when cytokines IL-2 and IL-12 are both combined. The difference for the other two conditions, IL-2 and $\mathrm{IL}-12$, is much larger. This difference is about 1.37 and 1.38 million cells, respectively.

Our findings indicate that T-cells exposed to slow rotation and cultured in IL-2 had higher survivability in the second experiment, but not in the first experiment compared to control cells. IL-12 alone had an antagonistic effect on cells. However, a combination of IL-2/IL-12 led to higher viability in the second experiment, but not in the first as compared to control cells. This suggests that there may be some variability between experiments that could be caused by the technical issues such as the discrepancy in cells counts or amount of cytokines added.

Figure 7 illustrates a long 3D aggregate structure for each condition: control, IL-2, IL-12, and a combination of IL-2 and IL-12. Each red square is $100 \mathrm{~mm}$ shown in Figure 7A. For comparison, the diameter of a typical red blood cell is $7 \mathrm{~mm}$. Control aggregate was measured to be about $12.2 \mathrm{~mm}$ in length by $2.0 \mathrm{~mm}$ in height. IL-2, IL-12, and IL-2/ IL-12 aggregates measured $\sim 16.0 \mathrm{~mm}$ in length and $2.0 \mathrm{~mm}$ in height, they have a similar size to one another. Control aggregate is a bit shorter compared to other conditions (15.8 $\mathrm{mm}$ for IL-2, $15 \mathrm{~mm}$ for IL-12, and 16 for IL-2 and IL-
12 combined). This suggests that aggregates are slightly longer when cytokines are present. Another physical visual characteristic is that aggregate shape in the presence of cytokines seems to adopt a more rugged form in the edges.

\section{Thermal and Centrifugation Study Using Human-Derived Breast and Colon Cancer Cells}

Next, we exposed human-derived breast MCF7 and colon HCT116 cancer cells to centrifugation and thermal stressors as described previously. Figure 9 depicts the evolution of both breast and colon cancer cells over the time span of $130 \mathrm{~h}$ or about 5.4 days when exposed at various temperatures: $37^{\circ} \mathrm{C}, 30^{\circ} \mathrm{C}, 20^{\circ} \mathrm{C}$, and $10^{\circ} \mathrm{C}$. The main reason to conduct these thermal studies for this time span is based on the possible suborbital flight delays and to allow for traveling time. The invitro experiment is expected to be at the PPF 3 days $(72 \mathrm{~h})$ before launch. Flight delays can be up to a couple of days so our analysis accounts for these contingencies. The initial number of cells for both sets was $8.5 \mathrm{M}$ cells. Overall, we observe a decrease in the number of breast cancer cells across all conditions when the cells are exposed to lower temperatures. Our first observation after $24 \mathrm{~h}$ showed a decreased number of HCT116 and MCF 7 cells at $37^{\circ} \mathrm{C}$. This decrease was also observed on these two sets of cancer cells at $30^{\circ} \mathrm{C}$, and on the MCF 7 at $20^{\circ} \mathrm{C}$, while the number of cells for both sets remained about the same when they were kept at $10^{\circ} \mathrm{C}$ after $24 \mathrm{~h}$. For example, at $37^{\circ} \mathrm{C}$ the number of MCF7 cells ranges between $7.8 \mathrm{M}$ and $6.0 \mathrm{M}$ cells during the $130 \mathrm{~h}$ experiment. At $30^{\circ} \mathrm{C}$, these cells' viability ranged from about 7.0 $\mathrm{M}$ to $4.0 \mathrm{M}$ cells. For $20^{\circ} \mathrm{C}$, the number of cells ranged 


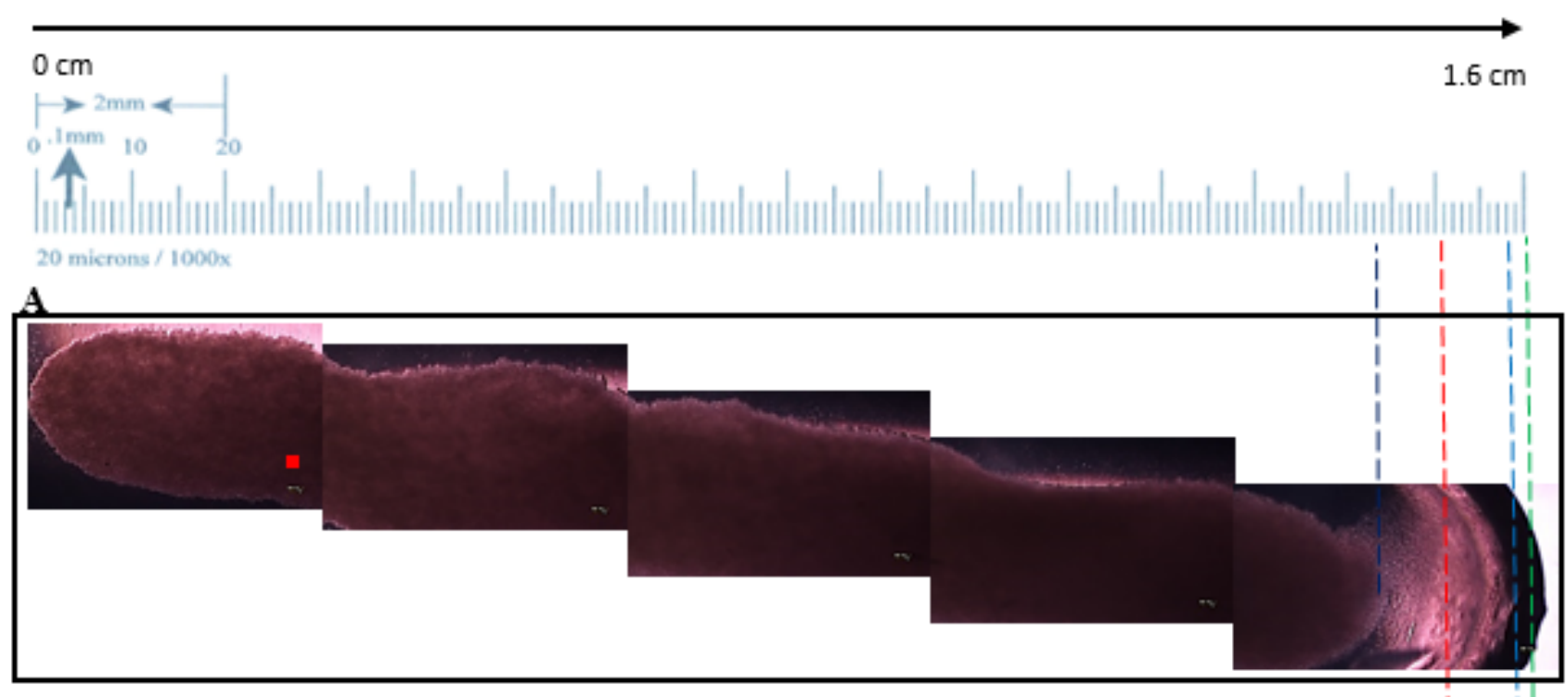

B

C
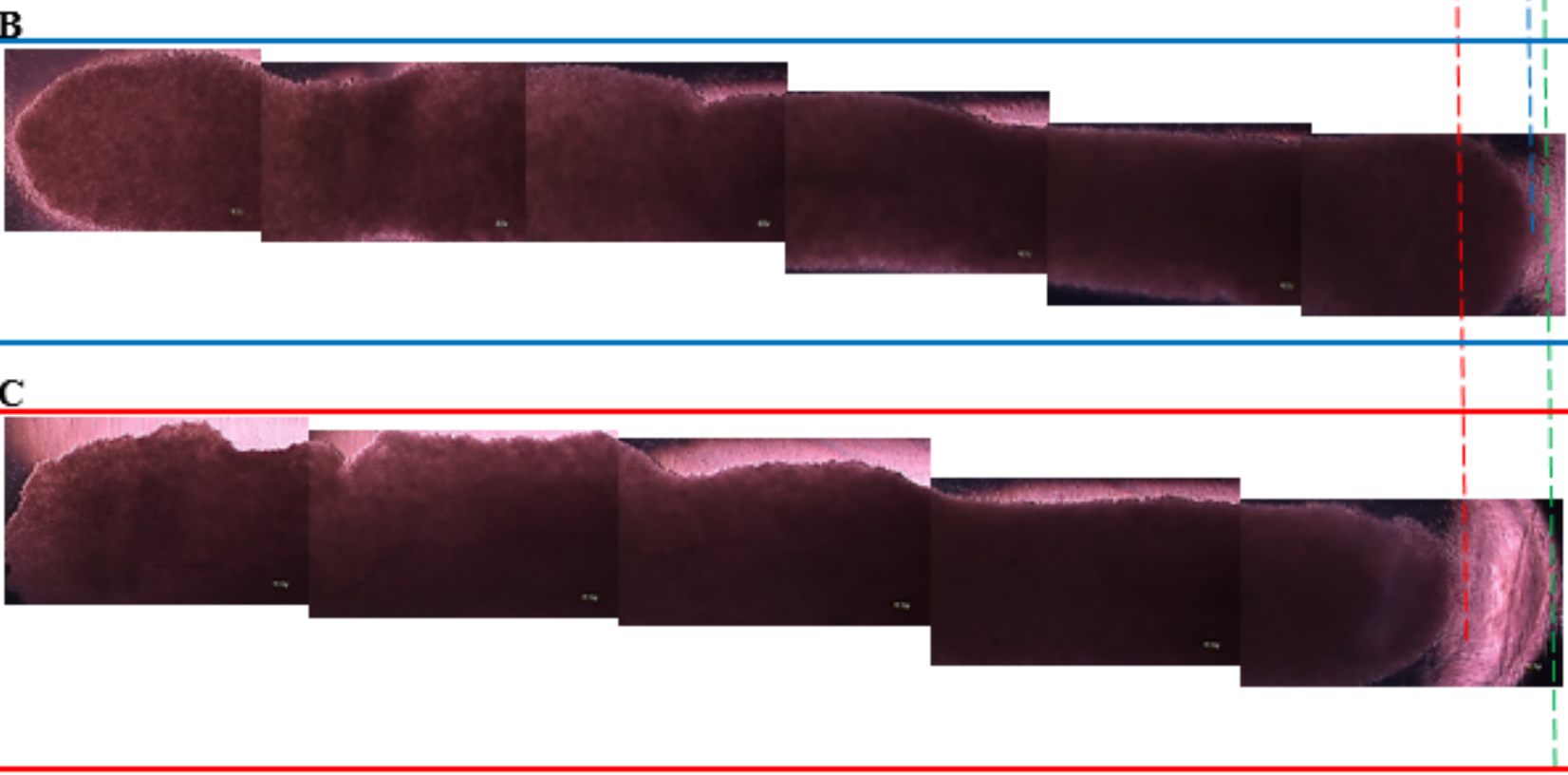

D

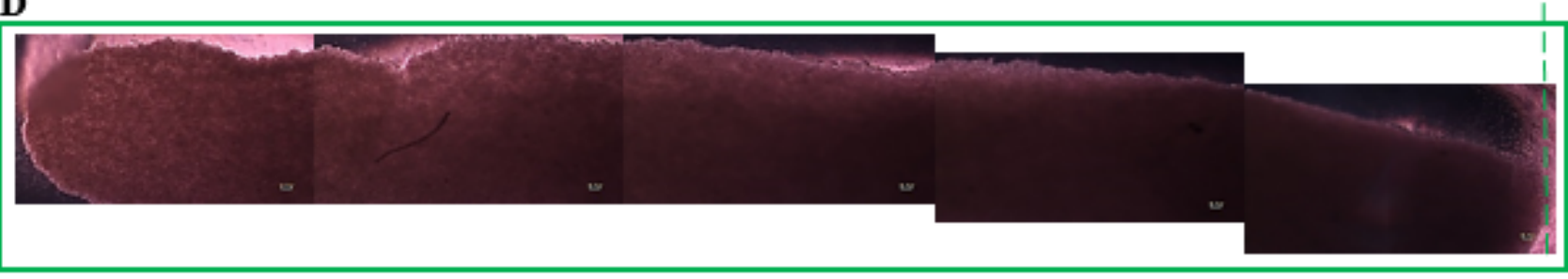

Figure 7. Cell aggregates visualized under the microscope at original magnification from one independent experiment. (A) Control. (B) IL-2. (C) IL-12. (D) IL-2 and IL-12. 
A
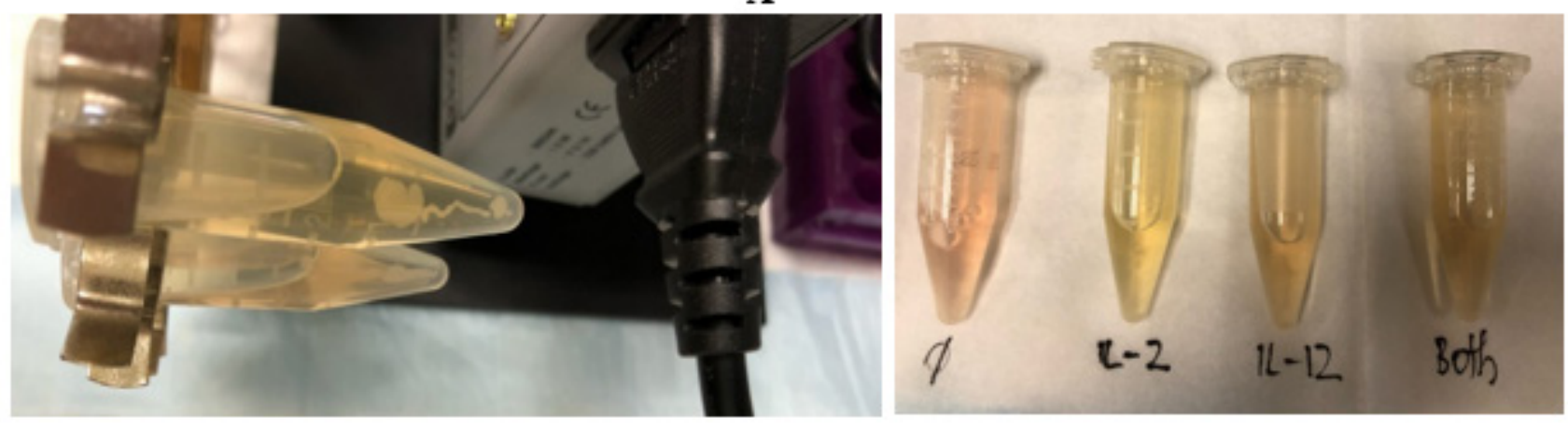

B
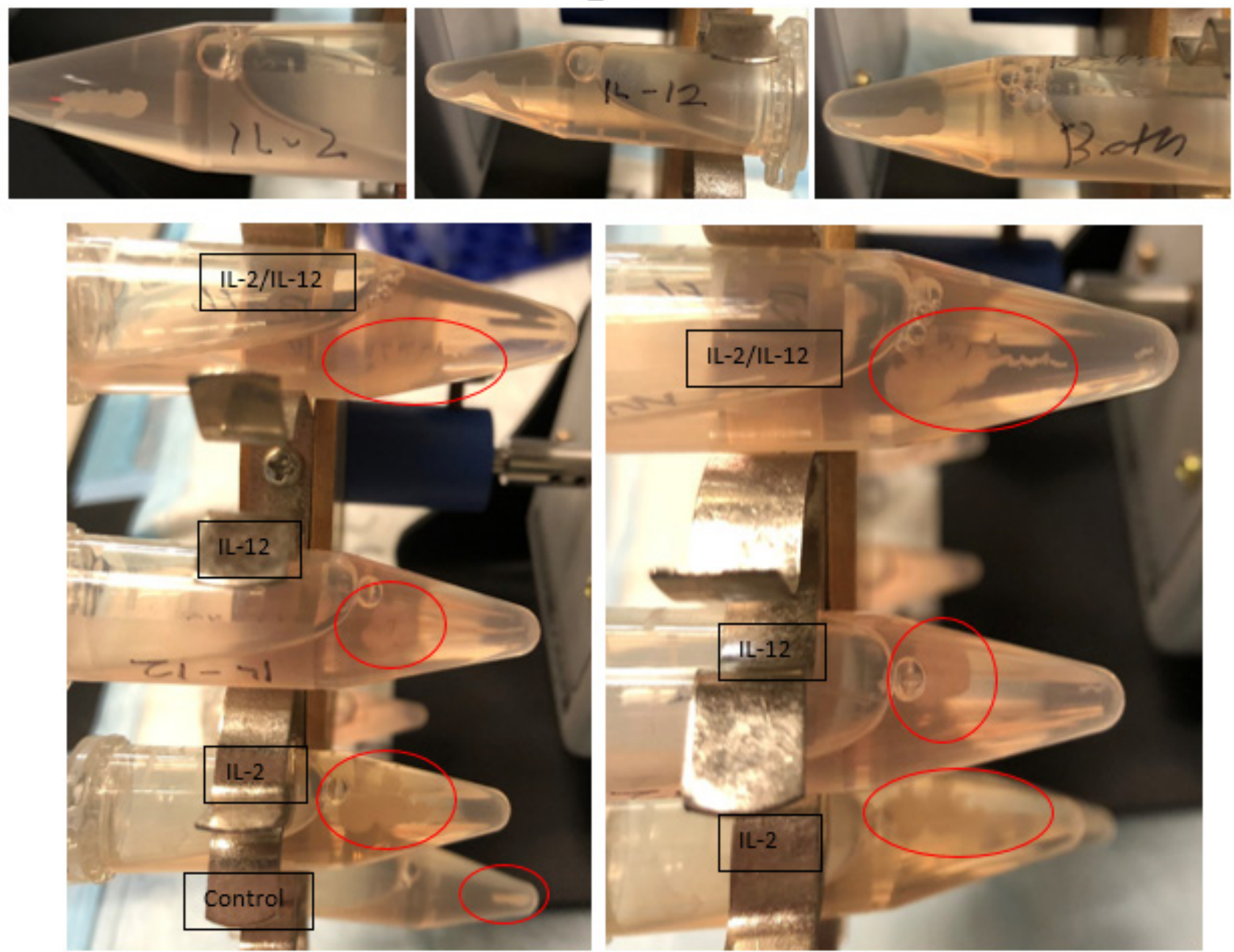

Figure 8. (A) IL-12 and IL-2/IL-12 on the left picture where the filament is seen on Day 6. Different colors observed across different conditions. (B) Zoom of some aggregates showing various geometries induced by clinostat effects for IL-2, IL-12, IL-2/IL-12, and control conditions. Sections circled in red show aggregates for different conditions. Images represent one independent experiment at original magnification. 

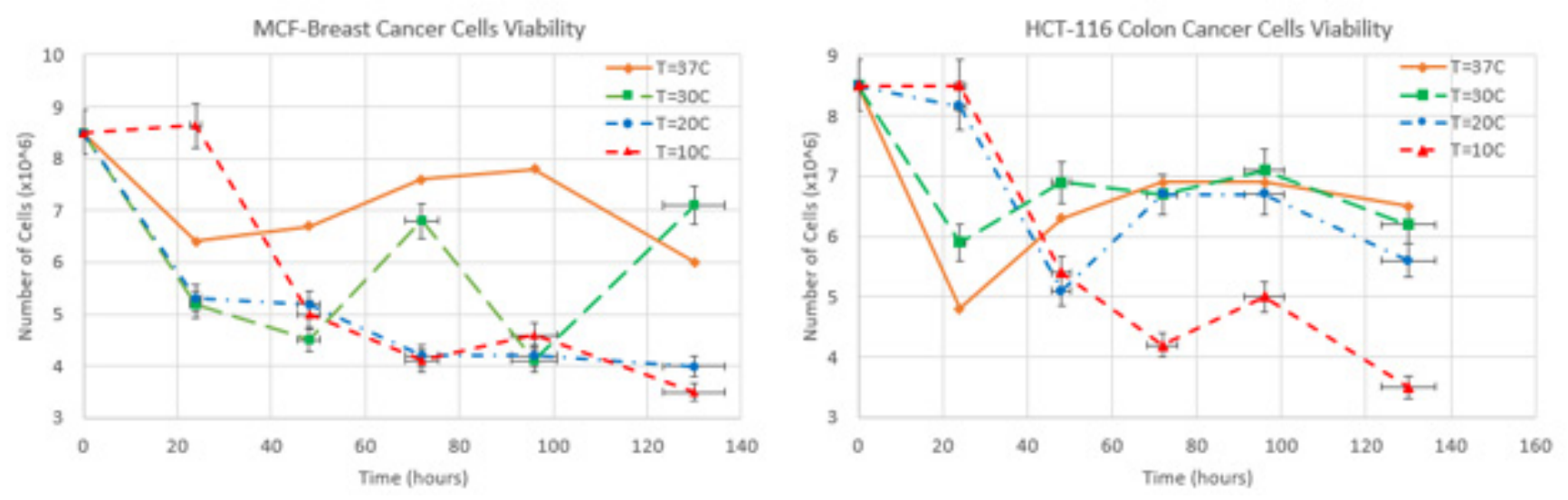

Figure 9. Survival rate of cancer cells exposed to different temperatures for a time span of $130 \mathrm{~h}$. (A) MCF7 breast cancer cells (single experiment). (B) Colon cancer cells (single experiment). Control cells at $37^{\circ} \mathrm{C}$ have no error since the other sets are compared with this set. This should be from two independent experiments and should be averages.

from about $5.3 \mathrm{M}$ to $4.0 \mathrm{M}$ cells. Finally, at $10^{\circ} \mathrm{C}$, the viability of these cells dropped from about $5.0 \mathrm{M}$ to $3.5 \mathrm{M}$ cells.

Colon cancer cells viability also was affected when exposed to various thermal baths during the same time span of $130 \mathrm{~h}$. One of the first visual differences we observe is that these cells seem to endure more the various thermal changes (higher number of cells at each temperature condition) with a lower difference in the number of cells at each time stamp. At $37^{\circ} \mathrm{C}$, they ranged from about $7.0 \mathrm{M}$ to $4.8 \mathrm{M}$ cells. Except for the first data point (cells measured after $24 \mathrm{~h}$ ), the other data points have a very close number of cells between about 7.0 $\mathrm{M}$ and $6.3 \mathrm{M}$ cells. At $30^{\circ} \mathrm{C}$, they ranged from $7.0 \mathrm{M}$ to $6.0 \mathrm{M}$ cells (once again higher than for breast cancer cells). At $20^{\circ} \mathrm{C}$, HCT116 cells ranged from $6.7 \mathrm{M}$ to $5.0 \mathrm{M}$ cells. Finally, at $10^{\circ} \mathrm{C}$ these cells ranged from about $5.3 \mathrm{M}$ to $3.5 \mathrm{M}$ cells. Together, data obtained from using two different human-derived cancer cells indicate that some cells, such as HCT116, might be less sensitive to temperature stressors compared to other cells and therefore might be better candidates for those invitro experiments that require exposing cells to their nonpreferential temperatures.

The mean \pm SD for the MCF7 cells were: $7.17 \pm 0.87$ million of cells $\left(T=37^{\circ} \mathrm{C}\right), 6.03 \pm 1.56$ million of cells $\left(T=30^{\circ} \mathrm{C}\right)$, $5.23 \pm 1.55$ million of cells $\left(T=20^{\circ} \mathrm{C}\right)$, and $5.72 \pm 2.07$ million of cells $\left(T=10^{\circ} \mathrm{C}\right)$. Similarly, the mean $\pm \mathrm{SD}$ for the HCT116 cells were: $6.65 \pm 1.09$ million of cells $\left(T=37^{\circ} \mathrm{C}\right), 6.88 \pm 0.83$ million of cells $\left(\mathrm{T}=30^{\circ} \mathrm{C}\right), 6.79 \pm 1.23$ million of cells $\left(\mathrm{T}=20^{\circ} \mathrm{C}\right)$, and $5.85 \pm 1.97$ million of cells $\left(\mathrm{T}=10^{\circ} \mathrm{C}\right)$. The relative error (RE) percentage was computed for each set of cells for both MCF7 and HCT116 cells, and observed that this error was larger for the breast cancer cells than for the colon cancer cells. Assuming the MCF cells at $37^{\circ} \mathrm{C}$ are the control cells, the RE percentage was $15.81 \%, 26.98 \%$, and $20.14 \%$ for $\mathrm{T}=37^{\circ} \mathrm{C}$,
$\mathrm{T}=30^{\circ} \mathrm{C}$, and $\mathrm{T}=20^{\circ} \mathrm{C}$, respectively. Similarly, if we assume the HCT 116 cells at $37^{\circ} \mathrm{C}$ to be the control cells, then the RE was $3.51 \%, 2.16 \%$, and $12.03 \%$, for $\mathrm{T}=37^{\circ} \mathrm{C}, \mathrm{T}=30^{\circ} \mathrm{C}$, and $\mathrm{T}=20^{\circ} \mathrm{C}$, respectively.

\section{DISCUSSION}

\section{Recommendations for Future Studies Using in vitro Suborbital Payload}

Taken together, our data show that T-cells are capable of surviving the temperatures they are likely to experience during the suborbital flight. In addition, we have obtained invaluable information giving us insights into which growth factors to use and how many viable T-cells we could expect to have back after the flight. Based on this information, we can design our actual payload in a more precise manner. Thus, we have a rationale to believe that it is feasible to get enough T-cells back to perform planned experiments. We have included a summary diagram outlining the experimental design (Figure 10). Furthermore, the need for high survivability of the T-cells is required for maximizing the outcome of the scientific suborbital experiment, due to possible delays or any other unforeseen circumstances.

As outlined in the preliminary data section, we have already tested the probability of the T-cells to survive at the predicted temperatures. However, the suborbital launch is a process where unpredictable can happen. Therefore, our science team will have equipment (e.g., mini fridge to store extra reagents, incubator to return any extra cell samples back to the laboratory, and ultra-low temperature cryogenic storage to cool cells to preserve flight samples below $-135^{\circ} \mathrm{C}$ 


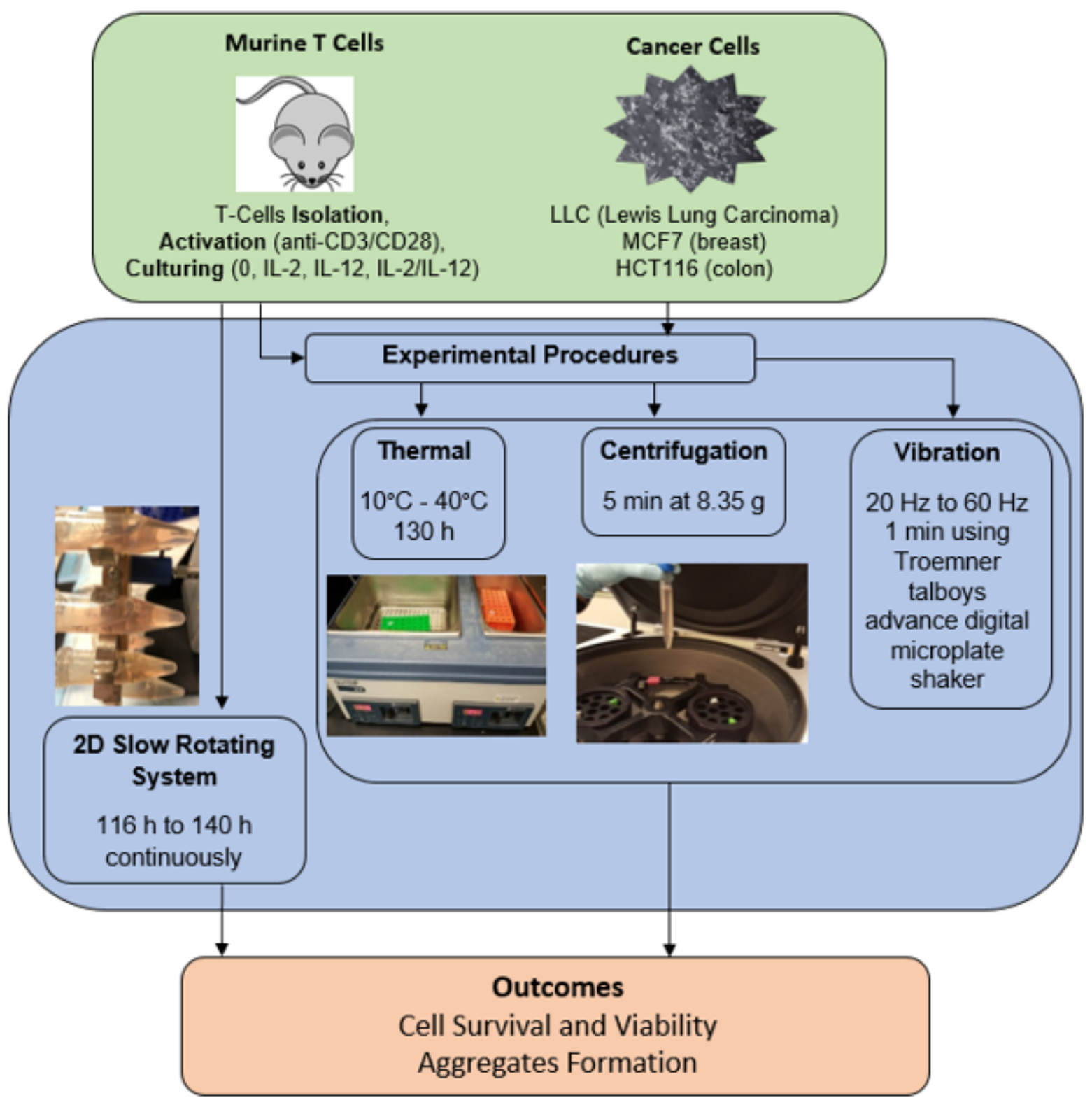

Figure 10. Experimental design diagram outlining the description and source of T-cells and cancer cells with conducted experimental procedures and outcomes.

for downstream applications, such as gene expression analysis) at the PPF in the launch site to increase the survival rate of cells after postflight operations. In addition, the scientific laboratory will be only $6 \mathrm{~h}$ away from the launch site, where samples will be processed right away, without any delay or shipping interference. Scientists onsite at the PPF in the West Texas Launch Site (WTLS) will also have special equipment (e.g., automatic cell counter, such as the Handheld Automated Cell Counter that not only provides information on cell counts, but it also shows the histograms of live/dead cell populations) to assess the viability of the cells avoiding the possible effect of transportation. Therefore, to eliminate the possible confounders, bias, and to increase the quality of science, we suggest having proper controls including cells generated the same way as flight cells, but left at the scientific laboratory; cells generated the same way as flight cells, but brought to the PPF at the WTLS (to compare to flight cells) and then flight cells. 
In addition, we suggest using some sensors' technology to monitor and record environmental changes pre-flight, onflight, and post-flight operations so that invaluable information could be recorded that later could be used for justification of scientific findings. There are several state-of-the-art sensors that could be used in science payloads, such as the edl-xyz data logger that measures temperature, relative humidity and acceleration, and the atmospheric sensor break out BME 280 , which measures temperature, humidity, and barometric pressure.

We did not assess separately the effect of centrifugation on T-cell viability. However, cells were exposed to centrifugation prior to thermal tests. Our data indicate that centrifugation at $8.35 \mathrm{~g}$ speed did not affect cells' viability. Finally, we recommend performing a visualization test of T-cell cultures during cell stimulation phase, so that additional cultures could be started in case cells fail to be activated.

Our experiments suggest that T-cells are more sensitive to temperature variations compared to cancer cells. Given that there are numerous murine- and human-derived cancer cells available on the market today, we strongly advocate testing their resistance to environmental stressors prior to actual flights. In the future, we would like to use various animal models (Choi et al., 2018), genetically engineered (humanized mice), as a new alternative for testing the effects of cancer immunotherapy and gaining insights about the behaviors of diverse cancers. Besides the simple tests conducted by our team, there are multiple other assays to assess cells viability, such as apoptosis assays, MTT (colorimetric assay for assessing cell metabolic activity), and many others. Failure to do so may result in unfortunate consequences, such as the lost opportunity to gain valuable scientific knowledge.

\section{Relevancy to human spaceflight}

Given that we are entering a renaissance era in human spaceflight with the increasing availability of the orbital and suborbital flights, the undeniable adverse effects of space travel should continue to be investigated to propel health and space medicine. However, there are many obstacles preventing us to clearly define the mechanisms accounting for microgravity-affected immune changes. Therefore, we are in urgent need to expand our knowledge on this topic so that we could design interventions to restore the downregulated immune system.

In this study, we demonstrated that T-cells and different types of cancer cells are capable of surviving suborbital flight stressors and could be used as an in-vitro model to study immunological parameters. However, some cells are more sensitive to stressors than others. More specifically, our data indicate that T-cells exposed to $30^{\circ} \mathrm{C}-37^{\circ} \mathrm{C}$ have the highest cell viability. On another hand, T-cells exposed to $40^{\circ} \mathrm{C}$ do not survive that well. Furthermore, naive T-cells, which are quiescent, must be first activated to induce cell division. Therefore, to optimize this process, we activated mouse T-cells using two commonly used interleukins, IL-2 and IL-12. Our findings demonstrate that adding IL-2 and IL12 to T-cell cultures provides a simple way to improve/extend the survivability of cells. In our T-cell experiment study, we observed the formation of aggregates after a few days when using a slow rotating device. The slow rotating allows for slight fluid flow around the cells, which helps increase multicellular geometrical structures or aggregates.

In addition to T-cells, we also assessed the survivability of different types of cancer cells. Our data indicate that cancer cells are less sensitive to thermal manipulations compared to T-cells. However, we noted the differences in resistance to stressors across different cancer cells. In particular, colon cancer cells, HCT116, were capable to survive even when exposed at very low temperatures, e.g., $10^{\circ} \mathrm{C}$. This could be explained by the aggressive behavior of these cells. Other cells, such as MCF7, were found to be more sensitive to stressors, but were still capable to survive at a reasonable rate. Together, our findings indicate that it is necessary to conduct feasibility studies prior to actual flights, so that the most appropriate in vitro model could be chosen for suborbital space experiments. Otherwise, the opportunity to collect invaluable scientific data could be lost.

Our long-term goal is to continue assessing the cellular processes induced by microgravity on the murine T-cells and other biological systems. Extensive research experiments have been conducted using the mice in ground lab settings and partial gravity, which will give insight about whether the partial gravity of the moon or mars will protect humans when subject to physiological changes in $0 g$ conditions (Masopust et al., 2017). Furthermore, it is unknown what countermeasures astronauts will require on these planets. Suborbital microgravity allows mimicking conditions more similar to what happens in the human body compared to the lab settings. From the suborbital flight data, we will assess the microgravity effect on the cellular processes of T-cells primed with different cytokines, which eventually will be used for clinical trials.

The evidence available to date from previous experiments assessing microgravity effect on T-cells demonstrates strong links between microgravity and downregulated immunity. However, we are still not in a position to clearly define the mechanisms mediating this effect. We hope that the data from our suborbital flight study that we are still analyzing will rule out many confounders, which were present in previous studies and will provide insights into which immunological parameters are affected by the brief exposure to microgravity, if any. Furthermore, the impact and significance of this project also lies in a unique collaborative team that will result in articulating outlining procedures and methodologies to prepare a scientific 
payload for suborbital flights. This will greatly assist for future experiments/payloads promoting a high quality of science.

Our study showed the importance of following specific and thorough experiment procedures to maximize the science data collection in lab settings before the actual suborbital flight. Previous research work (Hauschild et al., 2014) also highlights the importance of conducting simulated microgravity in a clinostat to assess the cell proliferation while emphasizing such in-vitro experiments should follow rigorous standardized cell culture conditions to enhance the outcome of the results. This will allow us to better establish the biological relevance of the changes observed in the immune system (Alwood et al., 2017). A better understanding of how gravity affects basic biological systems will allow us to understand the physiological adaptation during spaceflight (Clément, 2017) and what level of countermeasures will be more effective. Given that NASA Strategic Plan encourages using robust research at both basic and applied levels to make fundamental biological discoveries to address the emerging human risks of spaceflight environment, we strive to increase our collaborative network to improve techniques to enhance cancer research and risks-goals stated by the National Cancer Institute (NIC) and the National Institute of Health $(\mathrm{NIH})$ at the last American Society for Space Gravitational Research Conference in 2018.

\section{ACKNOWLEDGMENTS}

This work was partially supported by the Applied Aviation Sciences department at Embry-Riddle Aeronautical University during the Pl's first visit to the Medical University of South Carolina (MUSC) in the summer of 2016 and subsequent visits to both MUSC and the department of Molecular Medicine at UTHSCSA. We would like to thank Dr. Mark Rubinstein lab at MUSC and Dr. Mike Wargovich lab at UTHSCSA.

\section{REFERENCES}

Alwood JS, Ronca AE, Mains RC, Shelhamer MJ, Smith JD, Goodwin TJ (2017) From the bench to exploration medicine: NASA life sciences translational research for human exploration and habitation missions. NPJ Microgravity 3: 5

Bakos A, Varkonyi A, Minarovits J, Batkai L (2002) Effect of simulated microgravity on the production of IL-12 by PBMCs. Journal of Gravitational Physiology 9 (1): P293-294

Blue Origin (2016) New Shepard Payload User's Guide for Research and Education Missions. NSPM-MA0002-B Rev B. Available at: https://www.blueorigin.com/
Blue Origin (2017) New Shepard Payload User's Guide for Research and Education Missions. NSPM-MA0002-C Rev C. Available at: https://www.blueorigin.com/

Blue Origin (2018) New Shepard Payload User's Guide for Research and Education Missions. NSPM-MA0002-E Rev E. Available at: https://www.blueorigin.com/

Choi Y, Lee S, Kim K, Kim SH, Chung YJ, Lee C (2018) Studying cancer immunotherapy using patient-derived xenografts (PDXs) in humanized mice. Experimental \& Molecular Medicine 50(8): 99. doi:10.1038/s12276-018-0115-0

Choudhry H, Helmi N, Abdulaal WH, Zeyadi M, Zamzami MA, Wu W, Mahmoud MM, Warsi MK, Rasool M, Jamal MS (2018) Prospects of IL-2 in cancer immunotherapy. Biomed Research International 9056173

Clément G (2017) International roadmap for artificial gravity research. NPJ Microgravity 3: 29

Cogoli A (1997) Signal transduction in T lymphocytes in microgravity. Gravitational and Space Biology Bulletin: Publication of the American Society for Gravitational and Space Biology: 10 (2), 5-16

Crucian BE, Stowe RP, Pierson DL, Sams CF (2008) Immune system dysregulation following short- vs long-duration spaceflight. Aviation, Space and Environmental Medicine 79: 835-843

Eppendorf Handling Solutions. Basics in Centrifugation. Available at: https://handling solutions.eppendorf.com/sample-handling/usersafety/safe-use-of-centrifuges/basics-in-centrifugation/. Accessed November 29, 2018

Gridley DS, Slater JM, Luo-Owen X, Rizvi A, Chapes SK, Stodieck LS, Ferguson VL, Pecaut MJ (2009) Spaceflight effects on T lymphocyte distribution, function and gene expression. Journal of Applied Physiology 106: 194-202

Grimm D, Wehland M, Pietsch J, Aleshcheva G, Wise P, van Loon J, ... Bauer J (2014) Growing tissues in real and simulated microgravity: new methods for tissue engineering. Tissue Engineering. Part B, Reviews 20(6): 555-566. doi:10.1089/ten.TEB.2013.0704

Hauschild S, Tauber S, Lauber B, Thiel CS, Layer LE, Ullrich O (2014) $T$ cell regulation in microgravity - the current knowledge from in vitro experiments conducted in space, parabolic flights and groundbased facilities. Acta Astronautica 104: 365-377

Kessler JO, Hill NA, Strittmater R, Wiseley D (1998) Sedimenting particles and swimming micro-organisms in a rotating fluid. Advances in Space Research 21(8/9): 1269-1275

Klaus DM (2001) Clinostats and bioreactors. Gravitational \& Space Biology Bulletin 14(2): 55-64

Li Q, Mei Q, Huyan T, Xie L, Che S, Yang H, Zhang M, Huang $Q$ (2013) Effects of simulated microgravity on primary human NK cells. Astrobiology 13(8): 703-714

Licato LL, Grimm EA (1999) Multiple interleukin-2 signaling pathways differentially regulated by microgravity. Immunopharmacology 44: 273-279

Mangala LS, ZhangY, He Z, Emami K, Ramesh GT, Story M, Rohde $\mathrm{LH}, \mathrm{Wu} \mathrm{H}$ (2011) Effects of simulated microgravity on expression 
profile of microRNA in human lymphoblastoid cells. Journal of Biological Chemistry 286(37): 32483-32490

Masopust D, Sivula CP, Jameson SC (2017) Of mice, dirty mice, and men: Using mice to understand human immunology. Journal of Immunology (Baltimore, MD: 1950), 199(2): 383-388. doi:10.4049/ jimmunol.1700453

Manzano A, Herranz R, den Toom LA, te Slaa S, Borst G, Visser M, Medina FJ, van Loon JJWA (2018) Novel, Moon and Mars, partial gravity simulation paradigms and their effects on the balance between cell growth and cell proliferation during early plant development. NPJ Microgravity, 4(1): 9

Martinez EM, Yoshida MC, Candelario TLT, Fulford MH (2015) Spaceflight and simulated microgravity cause a significant reduction of key gene expression in early T-cell activation. American Journal of Physiology—Regulatory, Integrative and Comparative Physiology 308(6): R480-R488

Mehri R, Mavriplis C, Fenech M (2018) Red blood cell aggregates and their effect on non-Newtonian blood viscosity at low hematocrit in a two-fluid low shear rate microfluidic system. PLOS ONE, 13(7): e0199911. doi:10.1371/journal.pone.0199911

Moro-Aguilar R (2014) The new commercial suborbital vehicles: An opportunity for scientific and microgravity research. Microgravity Science and Technology 26: 219-227

NASA (2016) Evidence Report: Risk of Radiation Carcinogenesis. Human Research Program Space. Houston: Radiation Element

Nickerson CA, Pellis NR, Ott CM (2016) Effect of Spaceflight and Spaceflight Analogue Culture on Human and Microbial Cells. New York: Springer-Verlag. ISBN 978-1-4939-3276-4

Paulsen K, Thiel C, Timm J, Schmidt PM, Huber K, Tauber S, Hemmersbach R, Seibt D, Kroll H, Grote K, Zipp F, Schneider-Stock R, Cogoli A, Hilliger A, Engelmann F, Ullrich O (2010) Microgravityinduced alterations in signal transduction in cells of the immune system. Acta Astronautica 67:1116-1125

Pletser V, Migeotte PF, Legros JC, Deneyer B, Caron R (2016) The Suborbital Research Association: using suborbital platforms for science and student experiments. Microgravity Science and Technology 28(5): 529-544

Rubinstein MP, Su EW, Suriano S, Cloud CA, Andrijauskaite K, Kesarwani P, Schwartz KM, Williams KM, Johnson CB, Li M, Scurti GM, Salem ML, Paulos CM, Garrett-Mayer E, Mehrotra S, Cole DJ (2015) Interluekin-12 enhances the function and anti-tumor activity in murine and human CD8+ T cells. Cancer Immunology, Immunotherapy 64(5): 539-549

Sherman E, Barr V and Samelson LE (2013) Super-resolution characterization of TCR-dependent signaling clusters. Immunological Reviews 251(1): 21-35

Singh KP, Kumari R and Dumond J W (2010) Simulated microgravityinduced epigenetic changes in human lymphocytes. Journal of Cellular Biochemistry 111(1): 123-129
Tauber S, Hauschild S, Crescio C, Secchi C, Paulsen K, Pantaleo A, Saba A, Buttron I, Thiel CS, Cogoli A, Pippia P, Ullrich O (2013) Signal transduction in primary human $T$ lymphocytes in altered gravity—results of the MASER-12 suborbital space flight mission. Cell Communication and Signaling 11(1): 32

Thiel CS, Paulsen K, Bradacs G, Lust K, Tauber S, Dumrese C, Hilliger A, Schoppmann K, Biskup J, Gölz N, Sang C, Ziegler U, Grote KH, Zipp F, Zhuang F, Engelmann F, Hemmersbach R, Cogoli A, Ullrich O (2012) Rapid alterations of cell cycle control proteins in human T lymphocytes in microgravity. Cell Communication and Signaling 10(1): 1

Thiel CS, Hauschild S, Huge A, Tauber S, Lauber BA, Polzer J, Paulsen K, Lier H, Engelmann F, Schmitz B, Schütte A, Layer LL, Ullrich O (2017) Dynamic gene expression response to altered gravity in human T cells. Scientific Reports 7, Article number: 5204.

United Nations (2013) Teacher's Guide to Plant Experiments in Microgravity. Human Space Technology Initiative. United Nations Office at Vienna

van Loon JJWA (2016) Centrifuges for microgravity simulation. The Reduced Gravity Paradigm. Frontiers in Astronomy and Space Sciences 3: 21

Uva BM, Masini MA, Sturla M, Tagliafierro G, Strollo F (2002) Microgravity-induced programmed cell death in astrocytes. Journal of Gravitational Physiology 9(1): P275-276

Wagner EB, Charles JB, Cuttino CM (2009) Opportunities for research in space life sciences aboard commercial suborbital flights. Aviation, Space, and Environmental Medicine 80: 984-986

Wang P, Li X, Wang J, Gao D, Li Y, Li H, Chu Y, Zhang Z, Liu H, Jiang G, Cheng Z, Wang S, Dong J, Feng B, Chard LS, Lemoine NR, Wang $Y$ (2017) Re-designing Interleukin-12 to enhance its safety and potential as an anti-tumor immunotherapeutic agent. Nature Communications 8(1):1395 